\title{
Short Waves in Hungary, 1923 and 1946: Persistence, Chaos, and (Lack of) Control
}

\author{
Christopher A. Hartwell \\ Professor of Financial Systems Resilience \\ Bournemouth University, the Business School \\ Bournemouth, UK \\ chartwell@bournemouth.ac.uk
}

\author{
and \\ Professor \\ Kozminski University \\ Warsaw, Poland
}

\begin{abstract}
Monetary policies follow a complex and chaotic process, one that is enhanced when monetary growth is taken to the extreme, as in hyperinflation. While we have a basic understanding of the complex dynamics of hyperinflation, a less-explored phenomenon accompanying hyperinflationary episodes is the effect that they have on institutional development. Building on recent advances in economic history examining monetary policy and institutions, this analysis uses more explicit recourse to complexity theory and in particular complex adaptive systems to examine two separate hyperinflationary episodes in Hungary, 1923 and 1946. Delving into the institutional and cultural roots of the inflationary policies of the Hungarian government and detailing the institutional effects which succeeded hyperinflation, this paper shows that the twin experiences of Hungary were both chaotic and created a chaotic and complex aftermath, the results of which are still being felt. Indeed, Hungary's 1923 and especially its 1946 hyperinflation shows that some economic chaos cannot be restrained by political institutions and in fact the institutions themselves were changed. When staring into the abyss, Hungary also found that the abyss stared back.
\end{abstract}

JEL Codes: E42, N14, B52

Keywords: hyperinflation, complex adaptive systems, chaos, monetary policy, Hungary

ACKNOWLEDGEMENTS: The author has a huge debt of gratitude to Ladislav Krištoufek at the Institute of Economic Studies, Charles University, for his assistance in the chaos calculations. The author also wishes to thank the Editors, an anonymous referee, Jochen Runde, Pierre Siklos, Geoffrey Hodgson, and participants at the $2^{\text {nd }}$ Conference on Cliometrics and Complexity in Lyon, France, especially Steven Durlauf, Alan Kirman, and Pierre Borgnat. The author also thanks Tracy Bonham, Mike Viola, and Tim Christensen for their input during the writing of the paper.

FORTHCOMING, JOURNAL OF ECONOMIC BEHAVIOR AND ORGANIZATION 


\section{Introduction}

Monetary policy, and especially the targeting of a country's inflation rate, is a deliberate policy choice which economic policymakers tend to be in consensus on. However, inflation as a phenomenon, especially when it has escalated rapidly via monetary creation, can take on a life of its own, as the unshackling of inflationary pressures can result in hyperinflation. While there are several theories regarding the "rational" aspects of hyperinflation and how it arises via expectations and learning, the phenomenon of hyperinflation is little understood in relation to its effect on an economic system. This is especially true if one seeks to explain how seemingly unthinkable thresholds are breached, how economic agents cope in such an environment, and how hyperinflation is resolved in the short run versus its impact in the long run.

This paper asserts that hyperinflationary episodes, and indeed, much of monetary policy, can be understood best in a framework of complex adaptive systems (CAS). As with other CAS, hyperinflation is characterized by institutional feedbacks, chaos, and non-linear dynamics combining to create multiple and shifting equilibria. More importantly than the closed feedback loop occurring between inflation, money-printing, and expectations, however, is the fact that the phenomenon of hyperinflation does not operate within a limit cycle; in reality, the actions of the monetary authority can create chaos and upend the entire economic system (Albin and Foley 1998). While Berry and Kim (1997) spoke of long wave rhythms of prices punctuated by short-term oscillations, with crises occurring at long-wave peaks, hyperinflations appear to occur outside of longer-term trends and form a short-wave oscillation so violent that it creates new paths for the economy which experiences it. The consequences of hyperinflation are thus as unforeseen in the medium-term as they are predictable in the short-term (Durlauf 2012), threatening fragile governance systems (Duit and Galaz 2008), reshaping institutional structures, and reordering existing economic relationships. In extreme cases, an entire institutional system (including both political and economic institutions) can be rendered irrelevant and replaced by a new one.

To apply these tenets of complexity economics to hyperinflation, this paper uses the two episodes of Hungarian hyperinflation in the $20^{\text {th }}$ century, the first comparatively mild episode in 1923 and the more severe one of 1946, the worst hyperinflationary episode in history. While apologists have noted that the use of hyperinflation was not an accident but merely a "cleansing" and (successful) deliberate choice of the government (especially in relation to the 1946 hyperinflation, see Grossman and Horváth 2000), the longer-term effects on Hungary's political and economic institutions appears to disprove this assertion. Hungary was a new and independent state in 1918, tabula rasa in terms of its formal institutions, and the path for its institutional evolution was by no means set. With the first hyperinflation, there was an acceleration of state involvement in the economy and a deterioration of economic institutions, while the second hyperinflation effectively destroyed the rule of law in the country: inflation rates equivalent to prices doubling every 15.6 hours at the height of the hyperinflation meant that even the macroeconomic stabilization created immense disruptions to the country and left indeterminate multiple equilibria for basic macroeconomic variables (Paal 2000a). Seen through a CAS lens, the real effects unleashed were not even visible in short-term macroeconomic stabilization but in long-term governance destabilization (White 2017). Hungary's slide into communism in 1947 was a direct result of institutional reorientation started 24 years earlier, and the effects have lingered well beyond the take-over of Soviet-backed communists.

Building on recent advances in economic history examining monetary policy and institutions (Hartwell 2018), this analysis uses more explicit recourse to complexity theory and in particular complex adaptive systems to look at the Hungarian hyperinflationary episodes as a short wave that led to a much different longer-term rhythm. Delving into the institutional and cultural roots of the 
inflationary policy (i.e. the endogeneity of money), exploring the chaotic nature of the hyperinflation, and detailing the institutional effects which succeeded the crises, this paper shows that the demonstrably chaotic experience of Hungary in 1923 and in particular in 1946 had a much different effect than anticipated. Indeed, Rosser (1996:100) claims that, even in a chaotic environment, governments may create a stabilizing force through inertial tendencies, above all by the restraining power of institutions; the experience of hyperinflation in Hungary shows that some economic chaos cannot be restrained by political institutions, and in fact the political institutions themselves were changed. When staring into the abyss, Hungary also found that the abyss stared back.

\section{Complexity Dynamics, Monetary Policy, and Institutional Development}

\subsection{Complex Money, More Complex Hyperinflation}

The study of complexity theory and its application to economics has gathered steam in recent years, with contributions such as Rosser (1999), Durlauf (2005), and Arthur (2014) introducing and expanding upon the dynamics inherent in complex adaptive systems. As Duit and Galaz (2008) have summarized, complex adaptive systems are comprised of self-organizing and evolving agents who act on the basis of locally-available information; this inability to necessarily access global information, as well as the absence of an all-informed global controller (Rossler 1999), can result in multiple temporary equilibria and a tendency towards out-of-equilibrium dynamics. Moreover, as a distinctive feature of economic systems, the reality of "cross-cutting hierarchical organization" with many "tangled interactions" from other agents can engender limited systemic predictability unlike that found in nature (Arthur et al. 1997:4).

Several papers have applied these tenets to various facets of economic systems, with a comparatively smaller literature, clustered in the 1980s and 1990s, focusing on the complexities of macroeconomics and the complex properties of macroeconomic aggregates (highlights include Stutzer [1980], Leijonhufvud [1993], Day [1994], Colander [1996], and, more recently, Brock and Durlauf [2006]). Within this subset of complexity research, money and monetary policy has stood out for special treatment as a complex adaptive framework. The classic study of complex money is Barnett and Chen (1988), who examine Divisia monetary aggregates in the United States and determine that they contain clear evidence of mathematical chaos. Follow-on research from this work such as DeCoster and Mitchell (1991) and Serletis (1995) confirmed the presence of chaotic behavior in monetary aggregates and in the velocity of money, while DeCoster and Mitchell (1992) showed how such complex behavior in money led directly to an increase in chaos in most nominal variables of the economy.

Given the chaotic nature of money in its aggregate form, it is perhaps less surprising that monetary policy has also been characterized by chaotic and complex behavior. ${ }^{1}$ Soliman (1996:148), using the idea of basins of attraction, shows that "small disturbances may result in a qualitative change in the response of the [monetary] system," with "the long-term behavior of the system... dependent upon the initial conditions." Dwyer (1992), speaking of stabilization policies more generally, noted in a simple example that not every rule or policy may lead to chaotic behavior, but enough can so that monetary stabilization is fraught with difficulties.

\footnotetext{
${ }^{1}$ Indeed, each of the monetary aggregates surveyed in the work noted above are themselves a product of previous iterations of monetary policy.
} 
A key reason why monetary policy inherently displays chaotic attributes was noted by Friedman $(1953,1961)$ : incomplete information and variable lags can result in policy coming into effect at a point substantially different from the one in which the policy was formulated. As Solomon and Solomon (1991) show in the context of a nonlinear model of money in the United States, lags are one of the key elements which introduce instability and chaos into money supply aggregates (making them correspondingly harder to control). And Kelsey (1988), attempting to model chaos in business cycles, notes that there even though there are models in which monetary policy may be "effective" in achieving some vague outcomes, the chaos of the underlying system would make achieving an "optimal" policy nearly impossible (see also Ramsey 1990). More recently, Mohseni et al. (2015) examine chaotic behavior under various standard monetary policy rules and find that a forward-looking Taylor rule relying on rational expectations induces the most complex behavior.

Given that money exhibits complex and dynamic attributes and especially with regard to "normal" monetary policy, it can be surmised that the complexity and chaos of monetary aggregates and monetary policy multiplies in environments where monetary policy is used to the extreme (Marcet and Sargent 1989). Hyperinflation has been shown repeatedly in various data series and theoretical models to be characterized by large amounts of chaos and complexity. The classic treatment of nonlinearity in hyperinflation comes from Sargent and Wallace (1973), who show that printing money may be a globally-stable solution for a government but one which has locally non-stationary behavior containing inflation turbulence (as noted in Peel and Yadav [1995]). Building on this model, Burmeister and Wall $(1982,1987)$ show that the money supply process in Weimar Germany was endogenous, resulting in diverging expectations (which may have been rational for the individual actor) and bubble-like behavior.

The issue of diverging expectations was taken up in the next generation of hyperinflation models, which introduced bounded rationality in order to understand hyperinflationary dynamics; papers such as Barucci (2001), Marcet and Nicolini (2003), and Adam et al. (2006) relaxed assumptions of rationality in order to explore learning behavior in hyperinflationary environments but still found complex behavior. Adam et al. (2006:2743), in particular, touches implicitly upon the chaotic qualities of hyperinflation, noting that if there is limited information globally about other agents in the system, forecasting and expectation-formation becomes highly stochastic. This result comports both with real-world empirics of hyperinflationary paths and with economic intuition regarding the (lack of) universal availability of knowledge to economic agents at even the local level (Hayek 1945).

As Rao (2011) notes, this inability to access information makes hyperinflation a self-generating phenomenon, one that can generate chaotic behavior at even low levels of government spending and one which has a threshold beyond which hyperinflation explodes rather than dampens, gravitating towards a new attractor. Shown mathematically by Sornette et al. (2003:498), market prices converge to expected prices unless changes in market prices become exceedingly large, leading to amplified expectations and "super-exponential growth" of prices. However, this chaotic behavior is more than just the explosion of prices seen as hyperinflation continues, as Mizuno et al. (2002) prove. Specifically, they examine hyperinflationary paths in several real-world examples at both the macroscopic and microscopic level: seen from a macroscopic view, inflation dynamics may appear to follow a smooth path towards infinity, even at the double-exponential function, but at the microscopic level, there are still large fluctuations in prices, including movements downward, while in the midst of a hyperinflationary episode. With price expectations in a hyperinflationary episode highly dependent on local movements (Hercowitz 1981), any new information may create highly variable swings in different directions and towards new oscillations (Rao 2011). 


\subsection{Institutions and Complexity}

In addition to the list of traits associated with complexity, Durlauf (2005:F226) adds an additional characteristic which is of vast importance in understanding an economic ecosystem, namely nonergodicity, where "a shock at one point in time affects the long-run state of the system." This particular trait of complex adaptive systems appears to characterize many macroeconomic aggregates such as money (and the phenomenon of hyperinflation), but perhaps is even better suited to understanding the building blocks of an economy, its institutions.

Institutions are also characterized by complex adaptive behavior, path dependence, and, particularly, a high sensitivity to initial conditions (Hartwell 2017). But an association of institutions with CAS may not, at first glance, appear intuitive. At the local level, institutions are path-dependent but highly constrained, exhibiting high levels of inertia; indeed, what makes an institution an institution is its semi-permanence. Thus, as a practical matter, any institutional evolution is limited to small steps unless there is a revolution or regime change, a phase transition which requires large amounts of external energy to break an institution off of its prior path. The implication of this reality is that, over a short timeframe or seen from the perspective of probabilities of change, institutions at any given point have a low probability of sudden shifts in their composition, their intended goal, or their situation within an institutional structure. And given the low probability of structural change at any one point, it is more likely that an institution at any local point will only undergo tiny, perhaps imperceptible, changes that are better described as evolution.

However, when seen from a global perspective, institutions can and do evolve in any number of ways, including becoming more specialized and heterogenous; with time as an additional dimension, the interaction between environmental factors, policy, and other institutions can put specific institutions on long-term paths that are highly divergent (and unpredicted) from their local "solution." Using the words of Arthur (2014:6), "the economy is permanently in disruptive motion as agents explore, learn, and adapt. These disruptions... can get magnified into larger phenomena." One manifestation of this "larger phenomena" is precisely institutional change, as the jostling about of the economy at the global and macroeconomic level, pushed by macroeconomic policies, can project back to the local level. As noted, the probability of institutional change at every point in an institution's existence is miniscule but the probability is not zero. Thus, the myriad of institutional paths available over time are susceptible to being accessed at any one point precisely due to the effects of other institutions and their policies, so that while a regime break may not be observed in any discrete local solution, they do exist within one particular local solution. Put another way, macroeconomic policies may force a shift in the path of an institution that would not have existed previously in the "normal" interaction between an institution and its system.

Not all institutions will react in the same fashion, however, and institutional systems have various degrees of resistance to change. Lietaer et al. (2010) characterizes this design of institutions in a complex system as a trade-off between efficiency and resilience, with moves towards resilience requiring more flexibility (and hence less efficiency) and vice versa. Where institutions have moved towards efficiency almost exclusively, they can be characterized by too little diversity which allows for flexibility, an institutional analog to monoculture in ecology. On the other hand, very resilient institutions, those which are precisely the type to survive a crisis, could be amongst the least efficient or more pernicious (Dahlberg [2015] uses the example of terrorist or crime networks). Moreover, while markets are characterized by specialization and heterogeneity in terms of aggregate behavior (Kirman 2009), institutions may actually become more homogenous over time as they compete for scarce resources (a trend named "institutional isomorphism" by Dimaggio and 
Powell [1991]). The institutional path which is taken by an economy depends on the particular institution and on the particular shock, as not all shocks are created equal.

\subsection{Institutions and Hyperinflation}

The central question of this paper is to see how one shock, namely the chaos of hyperinflation, affects the economic system in which monetary institutions are embedded. Within the institutional system of any society, institutions perform various actions, including constraining, facilitating, generating information, and restricting access (and one institution can combine several of these attributes at any one time). Institutions do not exist in a vacuum, and as Colander (1996) notes, an institutional system often involves stabilizing institutions, institutions which help to restrict harmful human action and ensure the stability of the overall system at any point in time. Finally, a subset of these stabilizing institutions are the institutions that arise to support the needs of other institutions, creating a process model that specify course of action "for all points in the set of feasible outcomes" (Shubik 1997:264).

Money, properly conceived of as a social institution unto itself (Davis 2017), relies on just such a web of stabilizing institutions to function as a medium of exchange and a store of value (Marmefelt 2015). Given that hyperinflation inspires a higher order of chaotic effects in macroeconomic aggregates, it stands to reason that its corresponding effect on various other institutions (including those on which money depends) within an economy can be drastic. ${ }^{2}$ Indeed, Leijonhufvud (1997:333) notes that "inflation destroys institutional arrangements and routines on which people depend in order to come close to optimizing (in some objective instrumental sense)." Part of this reality derives from the fact, noted above, that institutional systems are forged of interdependent linkages reliant on shared heuristics and convergent expectations in a society: as Lewin (2016) correctly asserts, institutions, as the rules of the game that everyone has accepted, are shaped by shared assumptions, social mores, and understanding of the role of reward and penalty. Institutions are defined by their acceptance (in the political science literature, "legitimacy"), and this acceptance is the key to their effectiveness.

Hyperinflation violates these assumptions with regard to a crucial class of institutions, governance (political) institutions. In nearly all societies, there is an unspoken assumption that, while these institutions may be faulty, and people driven by political means, governance institutions still play a stabilizing role in the economy. Under such an assumption, governance institutions (and the people who run them) would not deliberately induce chaos into the economy or, if they were going to, the necessary checks and restraints would be in place to stop such an eventuality. But hyperinflation challenges that shared assumption, as a government chasing seignorage, focused on closing its budget deficit, acts as a destabilizing force on the entire economy on purpose.

The effects of this destabilization then spread to other institutions within a country, first to those institutions affiliated with the spread of money and then further outward. In fact, the effects of hyperinflation on institutions can be classified as one of three changes:

- Time Horizons;

- Strategy; and

- Allocation of Power Amongst Institutions

\footnotetext{
${ }^{2}$ Rosser and Rosser (1997) explore this thesis in the transition context, showing how inducing coordination failures can lead to a general economic collapse.
} 
Time Horizons. We have seen how expectations can narrow to an extremely local viewpoint, causing micro-movements in prices upward or downward even as hyperinflation is spiraling upwards out of control. In addition, time, and crucially, the perception of time, is also an important element of hyperinflationary effects. Under very high levels of inflation, time horizons bend and become incredibly shortened (Mizuno et al. 2002). Such an environment makes normal economic calculation difficult, if not impossible; indeed, if prices are doubling within one days' span of time, it is senseless to make plans for a year or even a week hence and intertemporal markets disappear (Leijonhufvud 1997). As Dornbusch (1992) notes in the context of hyperinflations from the 1980s, the economy converges to a spot market under hyperinflation, as relative prices have ceased to be useful as an informational tool and they take perceptions of space and time along with them.

As institutions are comprised of, moderated by, and created by people, and if human timespans are artificially compressed due to macroeconomic phenomena such as hyperinflation, institutions will also be forced to deal with shorter time horizons as well. And while such a compression could be handled by some institutions (property rights may remain unchanged and the judiciary may continue to enforce laws as immutable), other institutions are especially susceptible to disruption. An example of an institution vulnerable to compressed time horizons is the very sector which deals in time, the financial sector. By design, the financial sector has the role of structuring the rules of the game necessary for the utilization of fiat money, preserving markets in prices and interest rates (Shubik 1997:279). Moreover, financial institutions utilize two separate facets of time as part of their business: the first is obviously the use of interest, which represents the opportunity cost of tomorrow and provides information regarding trade-offs between consumption and investment. The second facet is, as Starr (2010) implicitly describes it, the fact that financial institutions transform short-term promises with no intrinsic value (fiat money) into illiquid capital which may persist for years into the future.

In a hyperinflationary environment, where time is substantially compressed, financial institutions are no longer able to play a stabilizing role as their time-sensitive functions are eradicated. With interest rates necessary to compensate foregone consumption approaching infinity, banks are hard-pressed to offer such rates to depositors, who are forced to find opportunities only within minute-to-minute differences in valuation (Shubik 1971). Similarly, transforming short-term claims to longer-term capital goods assumes that there is a time beyond the hyperinflation that firms are willing to purchase capital for (an assumption which is obvious outside of the hyperinflationary system but less obvious within it). As Leijonhufvud (1997:323) accurately describes it, hyperinflation causes "the strangulation of financial intermediation," a reality which has amplifies the effects of hyperinflation and removes an institution which could smooth prices from day to day. Even a brief burst of hyperinflation thus has deleterious effects on a country's financial sector (Bittencourt 2011).

Strategy. Beyond financial institutions, other institutions may be influenced in their operations or approach to other institutions, an approach which I have condensed here into the term "strategy." In a landmark piece of complexity scholarship, Lindgren (1991) demonstrated that a prisoner's dilemma game could reach several different equilibria based on knowledge of past moves and deeper interactions among participants; put another way, acquisition of information regarding the behavior of other agents in the game meant that deeper strategies were employed by participants, dominated simpler ones used at the outset.

Such a result is contingent on the information being available, and in Lindgren's simulation, where only two people were involved in the game, the transaction costs to obtaining this information were essentially zero (the information was perceived in real-time). In a hyperinflationary environment, 
however, information is much scarcer to obtain in the time frame needed to act upon it (information depreciates very quickly), and one of the main disseminators of information (the financial sector) is inoperable. The increased complexity of relations caused by the act of monetary policy profligacy thus necessarily leads to a simplification of strategy throughout the economy, a wave effect which ripples out from the hyperinflation and into institutions. Indeed, given that most institutions are designed to mitigate informational asymmetries and lower uncertainty or transaction costs, they can serve this function only by also enabling simplified strategies, relying on rules and simple heuristics.

While there is ample evidence in a bounded rationality framework that simple strategies may be effective (Martin and Moon 1992), the most effective strategies are those which are adaptable across a variety of environments (Payne and Bettman 2002). It is probable that the simple strategies which arise to be able to survive a hyperinflationary environment have little transferability across different institutional moments, meaning that institutions have become simpler and less effective in the formulation of Lietaer et al. (2010), the move towards efficiency in a highly-constrained environment means a corresponding (and incredibly large) drop in resilience. By adapting to the circumstances of hyperinflation, institutions have become less able to handle a return to "normalcy," in effect specializing themselves out of existence in an attempt to survive a crisis.

Allocation of Power. Finally, there are potentially more pernicious institutional effects beyond the obvious effect on the financial sector and on individual institutions, and which can extend to the entire institutional system. Monetary profligacy, by destroying the price system, forces a reliance on non-market transactions, and the largest purveyor of non-market transactions in an economy are the very same governance institutions which created the hyperinflation. With a crisis generated through creation of money, governance institutions are likely to jettison constraints and aggrandize power to themselves at the expense of the now-weakened market (Koyama and Johnson 2015).

This hypothesis is not idle conjecture: Hartwell (2018) shows that the effects of sustained monetary recklessness in interwar Poland eroded the rule of law and associated political institutions, leading directly to the establishment of a proto-fascist state with zero restraints on the executive. Other authors have made the link between hyperinflation in Germany and the rise of fascism, showing that the crisis in Weimar led directly to greater state intervention and an entrenched state apparatus ready to be overtaken by charismatic leaders (Overy 1996). Even the more recent Bolivian hyperinflation of the 1980s resulted in greater state intervention, although this came at the expense of erstwhile allies in the labour movement rather than the market writ large (Pastor Jr. 1991).

In each of these instances (and in many others), the state's involvement in the economy increased as a result of the hyperinflation and the resulting "stabilization," extending the power of the executive and shifting the balance of power within the previously-balanced institutional system. ${ }^{3}$ Whereas, prior to hyperinflation, the institutional arrangements within a country may have exhibited some sort of quasi-equilibrium or, to utilize complexity analysis, self-oscillation within a limit cycle, hyperinflation has the power to break the limit cycle and force new institutional arrangements within the country's phase space.

These effects, from monetary profligacy to hyperinflation to unmooring institutional change, are likely to be less linear in their effect depending upon the institution; that is, the strangling of the financial sector is a direct linear result of hyperinflation, but erosion of rule of law and other

\footnotetext{
${ }^{3}$ One need not castigate such changes as unfailingly "neoliberal" or "statist," although in practice they tend to be much more statist. The point is merely that the balance within an institutional system is altered, perhaps irrevocably, by hyperinflation.
} 
institutions may be more subject to chaotic and complex shifts. As the application of complexity shows us, in an environment which is already complex and subject to non-linearity, it is difficult to say for certain what effects may come about at the system level and how intense these effects might be (and what the timing of these effects will be as well). But what is certain about the change in institutions that hyperinflation induces is that they cannot be controlled by the agents who unleashed the hyperinflation in the first place.

The very phenomenon of hyperinflation itself is characterized by this uncontrollable nature, a point made by George and Oxley (1999:536), who note that hyperinflation cannot be influenced by control of the money supply but instead creates rational equilibria of infinite inflation that has "no inbuilt tendency to burst" in isolation from other institutions. As Akhmet et al. (2014:97) note, "the complex nature of economic systems implied by the presence of chaos may suggest that the evolution of economic variables is not only unpredictable, but also uncontrollable."

But although Akhmet et al. (2014) provide a method for identification of sources of chaos in macroeconomics and assert that chaos can be modified with slight changes to parameters controlled by government, such a simplistic solution cannot hold in a world of stubborn institutions and where governance itself is changing. Leijonhufvud (1997:323) dramatically describes how "the inability to finance the public sector turns into inability to govern" as a result of hyperinflation. As we have seen, this characterization of governance institutions may be too extreme, as they steadily aggrandize power during a hyperinflation (even if it apparently slipped away in the run-up to the monetary crisis). A better interpretation of this assertion is that governance becomes less effective in influencing long-term institutional paths at the exact same time that it obtains newfound powers to influence short-term macroeconomic aggregates.

Institutions, as a rule, have their own internal logic and path dependence, and while they can be "built" or influenced by outside sources, they also display a degree of independence from other institutions. Moreover, not all institutions have the same degree of influence in a system, and the shifting nature of economic relationships may mean shifting power dynamics in which institutions are influencing and which are influenced. Particular institutions thus subjected to hyperinflation may subsume other institutions, evolve to become more specialized in what they already do (e.g. private property institutions becoming hypervigilant on protection of property and less on its transfer), disappear entirely, or, in the case of some institutions, reorient themselves in a position accepting of the new allocation of power within the entire institutional system. With the shock to the system, however, the exact make-up of the institutional system after hyperinflation can never be perfectly foreseen: government may appear to have lost control of monetary policy during a hyperinflation only to regain it during stabilization, but control of the longer-term aspects of institutional change is less likely to be influenced by the best laid plans of politicians.

\section{Hungary, 1923 and 1946}

\subsection{A Tale of Two Hyperinflations}

In order to illustrate a practical application of this theory, we now turn to the two hyperinflations of Hungary in the $20^{\text {th }}$ century, in 1923 and the largest hyperinflation in history, the hyperinflation of 1946. The facts of both of these hyperinflations are well-known and well-studied but bear some repeating in order to understand the nonlinear nature of the monetary explosion and, in particular, the effect it had on institutional development. 
Hungary had seen sustained institutional volatility from its independence but within a narrow band of oscillations, at least with regard to its governance institutions. After a brief experiment with communism, Admiral Miklos Horthy was appointed regent of the newly-independent country by the National Assembly in 1920, where he was to remain until 1944. Weathering communist insurrection, external strife and disputes with Austria over borders, dealing with the loss of much of its pre-war territory and a far-weakened industrial base, enduring two abortive coups by former emperor Charles IV, and continuously threatening its neighbors (who then allied against the country), Hungary was a weak administrative state in search of some form of economic strength (Lopez and Mitchener 2018). Failing to find this strength in domestic coalitions and consensus and lacking an environment in which effective economic institutions could develop, Hungary applied to join the League of Nations in 1922 and was unanimously approved (Peterecz 2013).

As one of the key economic institutions concerned with the flow of money, Hungary's central bank followed a similar path to other monetary authorities in Central Europe. Originally constituted on Hungary's own volition as the Royal Hungarian State Bank in 1921, taking over the duties from the Habsburg-era Austro-Hungarian Bank, the State Bank had no degree of policy independence and was used by the government to finance its deficits in the early 1920s. Like many countries throughout Europe, the Hungarian budget was strained by various subsidies and fiscal transfers unaccounted for by "normal" monetary policymaking; publicly-owned enterprises operated at a continual and sizeable loss, revenue administration was practically non-existent, and reparations imposed by the victorious Allies continued to drain the budget (James 1992). Predictably, this approach of monetary finance of the state budget resulted in Hungary's first hyperinflation: although the hyperinflation is officially dated from 1923 to 1924 , where money grew 28\% per month and prices increased 33\% per month from April 1923 to March 1924 (Vegh 1992), prices were already on a steep increase starting from April 1922 (Sargent 1983). It was only with the creation of the Hungarian National Bank (MNB) in 1924, with a mandate for some form of policy independence (and at the behest of the League of Nations, see de Cecco [1997] and Peterecz [2013]), and with a concomitant infusion of money via the League's "Financial Reconstruction Plan," that the first hyperinflation was halted.

As part of the country's monetary reforms, a new currency (the pengö) was introduced in 1925 and Hungary entered the interwar gold exchange standard in a bid to jump-start the economy. A surge in foreign investment followed and the country's economic base began to rebuild, with industrial production indices moving upward slowly (increasing 4\% from 1927 to 1929, according to statistics from Mitchell [1992]). However, despite the success in bringing inflation down to more "normal" levels after the currency reform and especially while on the gold standard (Figure 1), the Hungarian government began to expand its involvement in the economy, including instituting protectionist tariffs on industrial imports and once again going on a borrowing binge (Cartledge 2006). Indeed, the Hungarian government continued to rely on fiscal policy to move the economy ahead, incurring debts of over US\$700 million by end-1930, with the bulk of this money going to "unproductive expenditures" (Feinstein et al. 2008). ${ }^{4}$

The Hungarian government also increased the fragility of the economic system by guaranteeing the financial sector, meaning banks, which had substantial exposure to the agricultural sector, were also dependent on state largess in the event of an economic downturn. This downturn came in 1931 as

\footnotetext{
${ }^{4}$ The largest such measure was a rebate scheme on wheat, meant to support prices in the event of worldwide conditions shifting, instituted in June 1930 and increased substantially in 1931 (Lynsky 1934). The rebate scheme incurred massive fiscal liabilities, the scale of which was unknown to the government itself until late 1931 (see James 1992) but it continued unabated in supplying capital to the dying flour mill industry (Pogány 2015).
} 
part of the global depression, and Hungary left the gold standard, imposed exchange controls, and saw a general financial crisis in the country (Macher 2015). Thereafter, Hungarian monetary authorities kept a very easy monetary stance in place throughout the rest of the interwar period, similar in essence to Japan, Germany, and Italy (Simmons 1996), while responding externally with additional trade restrictions and the institution of a clearing system with Germany (and eventually Italy), bypassing markets for planning (Berend 2001).

Figure 1 - CPI Change in Hungary, 1925 to 1931

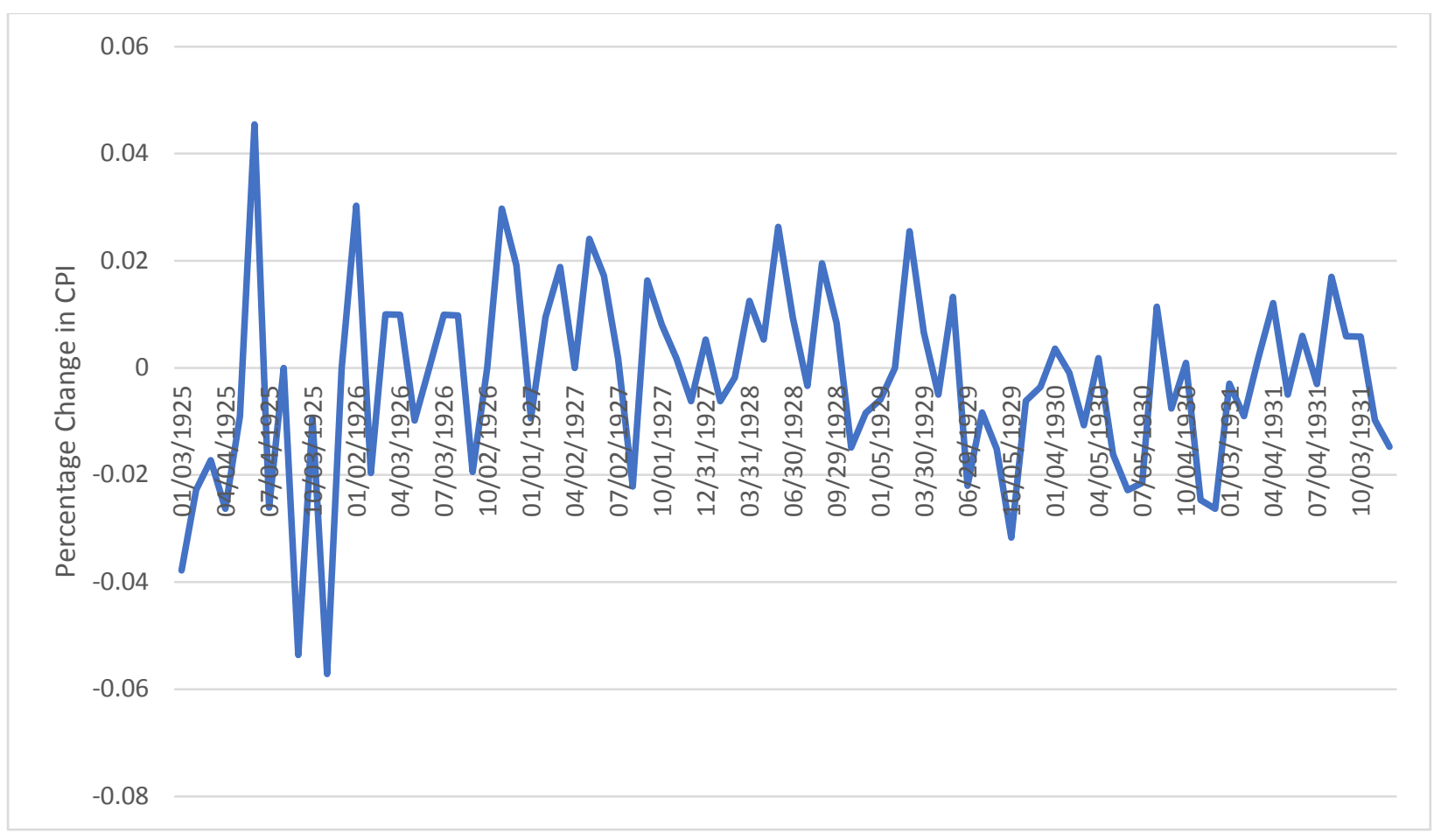

Source: Global Financial Database

Politically, Hungary remained a "closed anocracy" (as noted in the Polity IV rating system), a mixture of democratic and authoritarian political institutions and with political competitors drawn from the country's elite (with very little chance for entry from outsiders). As Wolf (2010) noted, Hungary saw an increase in "political tribalism," but had an average cabinet duration of 1.5 years (ironically better than any other country in Europe apart from Sweden and the Netherlands). Whereas the governance institutions of Hungary were by no means open and free, they had settled down into a quasi-stable equilibrium. The authoritarian impulses that had emerged at Hungarian independence and which had been accelerated by the hyperinflation in 1923-24 were inching closer towards fascism in the 1930s, but, as Cartledge (2006:362-363) notes, the "ultimate goal remained the creation of a unitary fascist state in Hungary but [the government] was prepared to move towards it gradually." It would take external intervention for this gradual evolution to be pushed aside, and, as the decade wore on, Hungary came to be politically dominated by Germany (Siklos 1990). In terms of its economic evolution, Hungarian economic institutions also became dependent on the foreign powers of the Axis and transformed so that they worked substantially on a non-market basis.

The destruction of the Second World War, and the fact that the last two years of the war saw intense fighting between Germany and the Soviet Union on Hungarian soil, put Hungary back to the situation it faced in 1918: a destroyed industrial base, no incumbent governing institutions, and nascent economic institutions modeled on international examples. Perhaps the only source of 
continuity in Hungary's institutional make-up was its monetary institutions, as the Hungarian National Bank began to increase the money supply almost immediately upon the end of hostilities. ${ }^{5}$ As Ecker-Racz (1946) detailed at the time, the amount of money in Hungarian treasury bills was approximately 5 billion pengő throughout July and August 1945, jumping to 15 billion by September $3^{\text {rd }}, 20$ billion by October $5^{\text {th }}, 50$ billion by October $30^{\text {th }}, 80$ billion by November $10^{\text {th }}, 200$ billion by November $19^{\text {th }}$, and 400 billion by the end of the year. According to Siklos (1990), the Hungarian government could only cover $6.5 \%$ of its expenditures by the end of 1945 by incoming revenue, and thus there was once again a reliance on seignorage to finance government spending. ${ }^{6}$

With the coming of 1946, the inflationary crisis, already underway, saw double-exponential growth (Mizuno et al. 2002). Part of the reason for the acceleration was due to the government's policy (again) of protecting the financial sector, indexing bank deposits (the so-called the Tax Pengó) to inflation and thus making seignorage gains lower than they would be while concurrently raising inflationary levels (Bomberger and Makinen 1980). In fact, as inflation grew, the popularity of the inflation-indexed accounts grew as a hedge against the rampant inflation, exacerbating the lack of seignorage obtained by the government and pushing inflation rates higher by design (Bomberger and Makinen 1983). As Paal (2000b) noted, there was unilateral Granger causality in the data from inflation to money growth, a fact which can be explained by the demand for indexed deposits and subsequent monetary policy; Paal also notes that this creation of an alternative liability by the same issuing authorities effectively created parallel currencies within the economy, one with higher rates of return and the other constantly depreciating.

The hyperinflation persisted throughout 1946 (see Figure 2), eventually reaching monthly inflation rates of 28 million percent in June 1946 and an unthinkable 12,952 trillion percent in July 1946 (Siklos 1991a). At one point in July 1946, prices doubled every 15.6 hours (Nogaro 1948), making normal economic calculation impossible, much less investment, while overall real money balances declined even as nominal money demand increased for indexed accounts (Caves et al. 2006). Indeed, Siklos (1991a) notes that the hyperinflation itself could not be taken as a homogenous event, attributing the changes in shifting demand for money and money growth as validation of the Lucas critique regarding expectations. And Paal (2000a) notes that plans for a stabilization were made as early as February 1946, the plans were publicized, and discussion of the plans occurred throughout the summer - most importantly, the date of the stabilization's commencement was formally set for August. Regardless, inflation reached stratospheric heights even after there was widespread expectation of stabilization.

The stabilization itself was comprised of a large number of measures, including the introduction of (another) new currency, the forint, the reintroduction of Article 50 of the Hungarian Central Bank charter (guaranteeing central bank independence), temporary imposition of a 100 percent reserve requirements for commercial banks, a sweeping reform of the tax system, and a reduction in the number of civil servants (Bomberger and Makinen 1983). Even after the stabilization, the money supply grew by 221 percent from August 31, 1946 to December 31, 1946, but price increases were much more muted, mainly because the Hungarian government had a strict limit on debt issuance until August 1947 (Siklos 1991a). With regard to other macroeconomic aggregates, Bomberger and

\footnotetext{
${ }^{5}$ Bomberger and Makinen (1983) relate a story told them by Arthur Karasz, a former official of the MNB, that when he returned to the bombed-out MNB building, they realized that they did not even have the money to pay for the ink to print currency and the Nazis had taken the plates back to Berlin. The Hungarian government actually had to borrow foreign exchange in order to begin the hyperinflation.

${ }^{6}$ Also noted in Bomberger and Makinen (1983), although perhaps a bit revisionist, is that many MNB officials had knowledge of the hyperinflation to come but were powerless to stop it.
} 
Makinen (1983:803) note that "evidence on the effect of stabilization on output and employment is spotty and unclear," as unemployment rose dramatically in the wake of the hyperinflation and national income also spiked; however, given the reconstruction from the war, it is unclear if the increase in output was related to the recovery or the stabilization package.

\subsection{Were the Hyperinflations Chaotic?}

The extant literature examining Hungarian monetary gyrations from a complexity perspective have come mainly from physics and have been concentrated on the chaotic nature of (primarily) the 1946 hyperinflation. For example, the already-cited Mizuno et al. (2002) study showed how the price increases in Hungary in 1946 both fit a double-exponential path but that price changes at the microscopic level were highly erratic and unstable even during the march to hyperinflation. Sornette et al. (2003:495) provide an extension to Mizuno et al. (2002) by examining Hungary 1946 (among other hyperinflations), and in doing so prove one of the tenets of a chaotic series - that it must be bounded - by noting that "a super-exponential growing inflation is unsustainable.... [and] the double-exponential law is nothing but a discrete-time approximation of a general power law growth endowed with a finite-time singularity at some critical time $t_{c}^{\prime \prime}$ (emphasis mine).

Indeed, the bounded nature of the Hungarian (and other) hyperinflations was confirmed by Szybisz and Szybisz (2017), who devised an extended nonlinear feedback model (ENLF) that predicted a critical mass for the Hungarian hyperinflation based on the stress that the economy would take (following on from their earlier work on Greece and Yugoslavia, see Szybisz and Szybisz [2009]). While a strict focus on only the time-series of monetary aggregates or prices would appear to be unbounded in a hyperinflation, the reliance on external conditions within the economy (and, crucially, other institutions) would have forced a bounding of money growth and inflation; as Marcet and Sargent (1989:135) showed in hyperinflations more generally, explosive growth of money near an upper bound of government deficits would have the entire monetary system "oscillate in a way typical of certain second-order, unstable difference equations." 
Figure 2 - Percentage Change of Money in Circulation in Hungary, 1920-1949

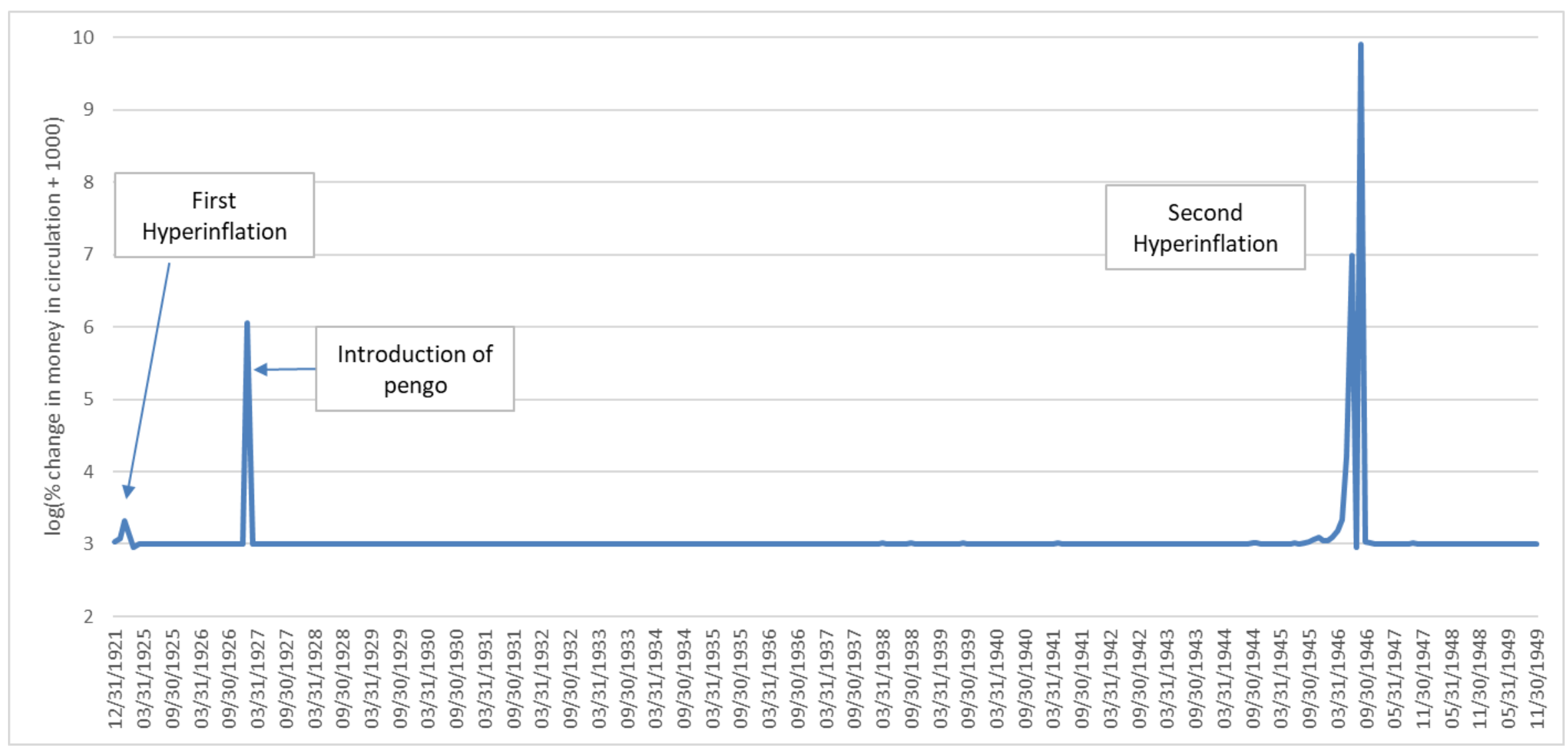

Source: Author's calculations based on data from the Global Financial Database. 
But despite the vast amount of modelling done on the chaotic attributes of the second Hungarian hyperinflation, however, little work has been done in testing empirically the chaotic nature of either the first or the second hyperinflation. I attempt to rectify this omission here by formally testing for nonlinear and chaotic behavior on several series of Hungarian monetary and exchange rate data during the two episodes of hyperinflation, including:

- Levels of and change in the monthly exchange rate (Hungarian korona versus the Swiss franc) from January 1914 to December 1926;

- Levels of and change in the monthly exchange rate index of Hungarian currency movements from January 1914 to December 1925;

- Percentage change in bills in circulation, monthly, from December 1922 to December 1938

- Level (in logs) and growth of the daily "Cost of Living Index" (as shown in Siklos 1990), from January 1 to July 24, 1946;

- Level and change in the daily exchange rate (pengő to US dollar), from October 22, 1945 to May 14, 1946; and

- Level (in logs) and growth of the daily index of prices denominated in tax pengő, January 1 through July 29, 1946.

The provenance of the data and more detail on how it is calculated is shown in the Data Appendix.

The first test to be used is the BDS test of Brock et al. (1987 and 1996), often used for testing nonlinearity in time-series data. The BDS procedure is based on the Grassberger and Procaccia (1983) correlation integral, with the integral measuring the fraction of two data-point pairs which lie within the tolerance distance $\varepsilon$ for any chosen embedding dimension $m$; as Kočenda (2001:340) notes, "by using pairs of $m$-histories that too often cluster together within a specific distance $\varepsilon$, the BDS test is able to reveal hidden patterns that should not occur in truly randomly distributed data." In other words, the BDS test statistic measures the statistical significance of these correlation dimension calculations, with the null hypothesis of the test that the data are independently and identically distributed and rejection of the null implying nonlinearity in the series. For our purposes, the BDS test has been shown to have a higher power for tests of stochastic or chaotic independence than other statistical techniques (Brooks 1996). ${ }^{7}$ As counseled by Brock et al. (1991), the $m$-dimensions are used for our examination are in a range from 2 to 5 and $\varepsilon$ is set at intervals of 0.5 standard deviations of the filtered series ranging from 0.5 to $2.0{ }^{8}$ Additionally, as the time-series of this data is generally fairly short ( $n$ between 100 and 600 observations), bootstrapped standard errors are used to generate the confidence intervals.

The BDS test results on each of the aforementioned series are shown in Table 1 for the 1923 hyperinflation (and, in the case of the currency series, its aftermath) and Table 2 for the 1946 hyperinflation. As can be seen, there is very strong evidence of non-linearity in both episodes, with the exchange rate levels, changes in exchange rate levels, and changes in the exchange rate index all significant at the $1 \%$ level for epsilons ranging from 0.5 to 1.5 standard deviations; only for epsilons of 1.0 and 1.5 is the currency in circulation metric significant only at the $5 \%$ level, while at an epsilon of 2 standard deviations the significance also comes down slightly for the change in the exchange rate levels

\footnotetext{
${ }^{7}$ The mathematics behind the BDS test have been lain out amply elsewhere in the literature and need not be repeated here.

${ }^{8}$ Brock et al. (1991) advise using an epsilon between 0.5 and 2 standard deviations of the filtered data, which is why that is utilized here.
} 
and in the change in the index, but at no point and at no $m$-dimension is the null accepted. Even stronger results hold for the 1946 hyperinflation, with exchange rates and two separate price indexes rejecting the null at the $1 \%$ level through all epsilon choices. The only outlier in the 1946 data is for the changes in the cost of living index, which shows strong non-linearity until two standard deviations are used, and then the null cannot be rejected. However, despite this one aberration, it appears that the null of linearity can be safely rejected for nearly all of the series from the Hungarian hyperinflations under examination.

[Tables 1 and 2 here]

These results of the BDS test can, as Bartlett and Serletis (2000:711) note, be used "to produce indirect evidence about nonlinear dependence [whether chaotic (i.e., nonlinear deterministic) or stochastic], which is necessary but not sufficient for chaos." Thus, I also turn to one of the most common approaches for detecting chaos, namely the calculation of Lyapunov exponents (as shown in Wolf et al. 1985). This approach defines the Lyapunov spectrum within a one-dimensional space in terms of the length of the ellipsoidal principal axis of the series, denoted $p_{i}(t)$ :

$$
\text { (1) } \lambda=\lim _{t \rightarrow \infty} \frac{1}{t} \log _{2} \frac{p_{i}(t)}{p_{i}(0)}
$$

The presence of positive Lyapunov exponents calculated from Equation 1 is taken as evidence of complex and chaotic effects, as such motion cannot be said to occur with a bounded attractor; as Wolf et al. (1985:287) note, "Each positive exponent reflects a 'direction' in which the system experiences the repeated stretching and folding that decorrelates nearby states on the attractor. Therefore, the longterm behavior of an initial condition that is specified with any uncertainty cannot be predicted; this is chaos."

For this paper, Lyapunov exponents are calculated on daily data for the cost of living index and exchange rates from 1945 to 1946, while monthly data is used for currency in circulation from 1921 to 1925: from these series, a maximal Lyapunov exponent (MLE) is extracted, with positive MLEs used to suggest chaotic behavior. Given that there is much debate in the literature on the reliability of these exponents being derived from economic data, in order to ascertain the statistical significance of the calculated exponents, bootstrapped confidence intervals in the vein of Fernández-Rodríguez et al. (2005) are also computed around these MLEs. In particular, the amplitude adjusted Fourier transform (AAFT) surrogate method of Theiler et al. (1992) is used, where the original data series is ranked and transformed into a Gaussian series via sorting but with preservation of the original amplitude distribution (Maiwald et al. 2008). MLEs are then estimated on the surrogate series created by the Gaussian transformation and bootstrapped over a thousand iterations, with the results forming a distribution of the Lyapunov exponent under the null of no chaos (again with the same distributional properties and linear autocorrelation structure as the original series). This bootstrapping exercise thus creates confidence intervals which allow for testing the original exponent derived from the actual data against the null of no chaos, allowing us to ascertain how strong the significance of the original finding is.

The results of this exercise are shown in Table 3. For the 1923 hyperinflation, using monthly data on exchange rates, all series show positive Lyapunov exponents; the change in the exchange rate index and the level of the exchange rate have marginal significance, both at the $11 \%$ level, while the changes in the 
exchange rate show substantial proof of chaotic dynamics. Similarly, using the actual number of bills in circulation from 1922 to 1938 , we see very strong evidence of chaotic effects, significant at the $2 \%$ level. Keeping in mind that this data is only available on a monthly basis, it is likely that evidence of chaos would be even more prevalent at a daily frequency (work is ongoing on attempting to identify if this data exists). Turning to 1946, there are also positive Lyapunov exponents for each series under examination, but the price indices - perhaps through measurement error, lags in information, or underlying stability - show little significant evidence of chaotic dynamics. As with 1923, the exchange rate (a series more in tune with forward-looking expectations and sentiment) provides substantial backing for the chaotic nature of the hyperinflation, with the Lyapunov exponent significant at the $3 \%$ level.

Given this examination, it appears we may conclude that chaotic effects were present in the Hungarian hyperinflation, although standard macroeconomic measurements such as the CPI may not have been sensitive enough (or had enough information) to capture them. In particular, the exchange rate, as a measure of forward expectations, appears to be much more sensitive to chaos and this was reflected in the results. At the same time, focusing on the amount of money in circulation also revealed strong chaotic effects.

\subsection{The Aftermath: The Path Unwinds}

While establishing that the hyperinflations in Hungary was chaotic is an important step forward, it is not the main purpose of this paper, as we are more interested in understanding the chaotic effects unleashed on institutions. The Hungarian hyperinflations have thus far been noted as little more than a historical curiosity and, by economists, as a case study of how hyperinflation can affect unemployment (Sargent 1983), money balances (Anderson et al. 1988), money demand (Engsted 1998; Paal 2000b), and eventually, how hyperinflations can be stabilized (Siklos 1991a). The conventional wisdom regarding the hyperinflation is that, while it had some unique circumstances contributing to its onset (Bomberger and Makinen 1980) it had little long-lasting macroeconomic effects (Sargent 1983) and that the stabilization was a complete success (Bomberger and Makinen 1983). Indeed, according to Grossman and Horváth (2000), the hyperinflation was even necessary to wring out the massive distortions in the Hungarian economy from the war years: calling the destruction to the economy wrought by war a "massive supply shock," they argue that it was this shock which sparked the hyperinflation and that government policy was deliberately set to harness inflationary revenue that could not be obtained by other means. At the same, they argue that the inflation was also meant to induce entrepreneurs to invest in productive activities by lowering the real cost of capital and real wages.

Not all economists agree about the short-term effects of the hyperinflation, however, nor about the success of the stabilization. Siklos (1990), without explicitly using the term, shows the chaotic nature of the money-price nexus during the hyperinflation and how the hyperinflation created several equilibria depending upon the expectations created by the Hungarian government at that moment in time. Similarly, Siklos (1991b), focusing on an attempted fiscal reform in the middle of the hyperinflation, makes the point that, after six months of insanity, Hungarians were "immunized" against governmental reforms and were prepared for any stabilization to fail. Paal (2000a) also makes a convincing case that the stabilization was itself destabilizing to macroeconomic aggregates, as it created multiple equilibria, 
clouded information dissemination mechanisms (i.e. prices), and, most damningly, actually exacerbated the hyperinflation, making it far more severe than it should have been at the moment.

While the experience of Hungary's hyperinflations did incalculable damage to the economy of the country, more importantly for our purposes, they created a distinct and harmful institutional path which was a direct result of the monetary chaos and distinct from the country's previous institutional trends. Perhaps Hungary's institutional path was perhaps not as unconstrained as other economic systems, as the reality of post-World War II Europe and the looming shadow of Stalin's Soviet Union (coupled with communist takeovers throughout Central and Eastern Europe) made Hungary's institutional choices limited. But while the governance institutions of Hungary had never been marked by a liberal bent, the extent of the authoritarian leanings within the government appeared to have settled from the Horthy years and persisted throughout the war. In fact, it was only with the coup of the Arrow Cross party in October 1944 that Hungarian governance institutions became brazenly authoritarian, a trend which was set to continue as the ideology of fascism gave way to its sister ideology, communism (Figure 3).

Figure 3 - Polity IV “polity2" Indicator for Hungary, 1918-1963

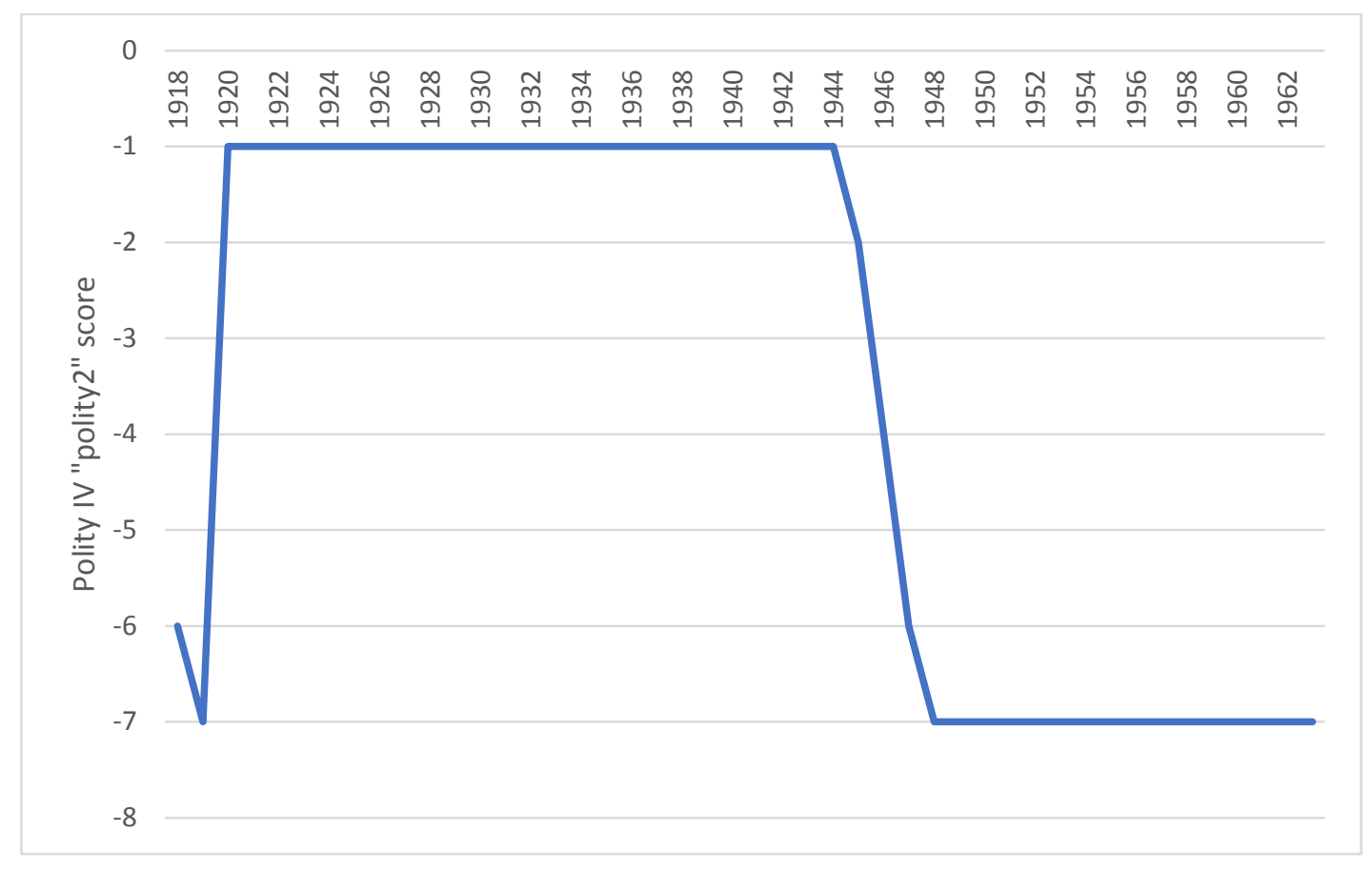

Despite the war and the fascist interregnum, Hungary's institutional make-up and its institutional path for the long-term were not predetermined, especially with regard to its economic institutions. The Polity IV rating, done on an annual basis and shown in Figure 3, obscures the reality of institutional changes occurring month to month. A more nuanced measure, the Max Range "regime value" (Rånge and Sandberg 2017), better shows the positive conditions that Hungary faced in 1945 (Figure 4). ${ }^{9}$ In the first

\footnotetext{
${ }^{9}$ The Max Range regime value contains within it four sub-variables, including regime type, accountability structure, executive strength, and whether a regime is "normal" or "interim." Each is coded from 0 to 25 , meaning the entire index ranges from 0 to 100 . The interpretation of the index is that higher numbers represent more democratic
} 
instance, the country saw a relatively free and fair election which gave a majority to the independent Smallholder's Party, a party which espoused traditional Hungarian values and commanded broad support in its economic policies the ruined country. Moreover, while Hungary's sovereignty (as an Axis power) was limited in the immediate post-war era, its economic institutions were independent and indigenous, and even the Central Bank was granted by statute a degree of nominal independence from the government (although, as Bomberger and Makinen [1980] correctly note, the Article guaranteeing this independence was suspended during the war, it was reinstated as part of the 1946 stabilization reforms).

The first hyperinflation may have nudged Hungary towards authoritarian governance, but it was the second hyperinflation that put it over the edge. Indeed, the relatively confined orbit in which Hungarian institutions (political and economic) were ensconced in for the interwar and early war period was broken wide open in the post-war era by the hyperinflation. In the first instance, the strangulation of the financial sector paved the way for communist ideology, predicated as it was on the belief that financial intermediation was an accounting problem to be solved and not a tool for transforming savings. Paal (2000a:600) also notes that a key plank of the post-hyperinflation Hungarian stabilization was to expressly limit the amount of credit which banks could issue, a policy which not only retarded the recovery of the financial sector but resulted in "indeterminacy of the initial post-stabilization real interest rate." In other words, the price system was broken by the hyperinflation, and even in its wake intertemporal markets were held in check by the ongoing "stabilization" by political institutions.

Figure 4 - The Max Range "Regime Value" Indicator in Hungary, 1918-1949

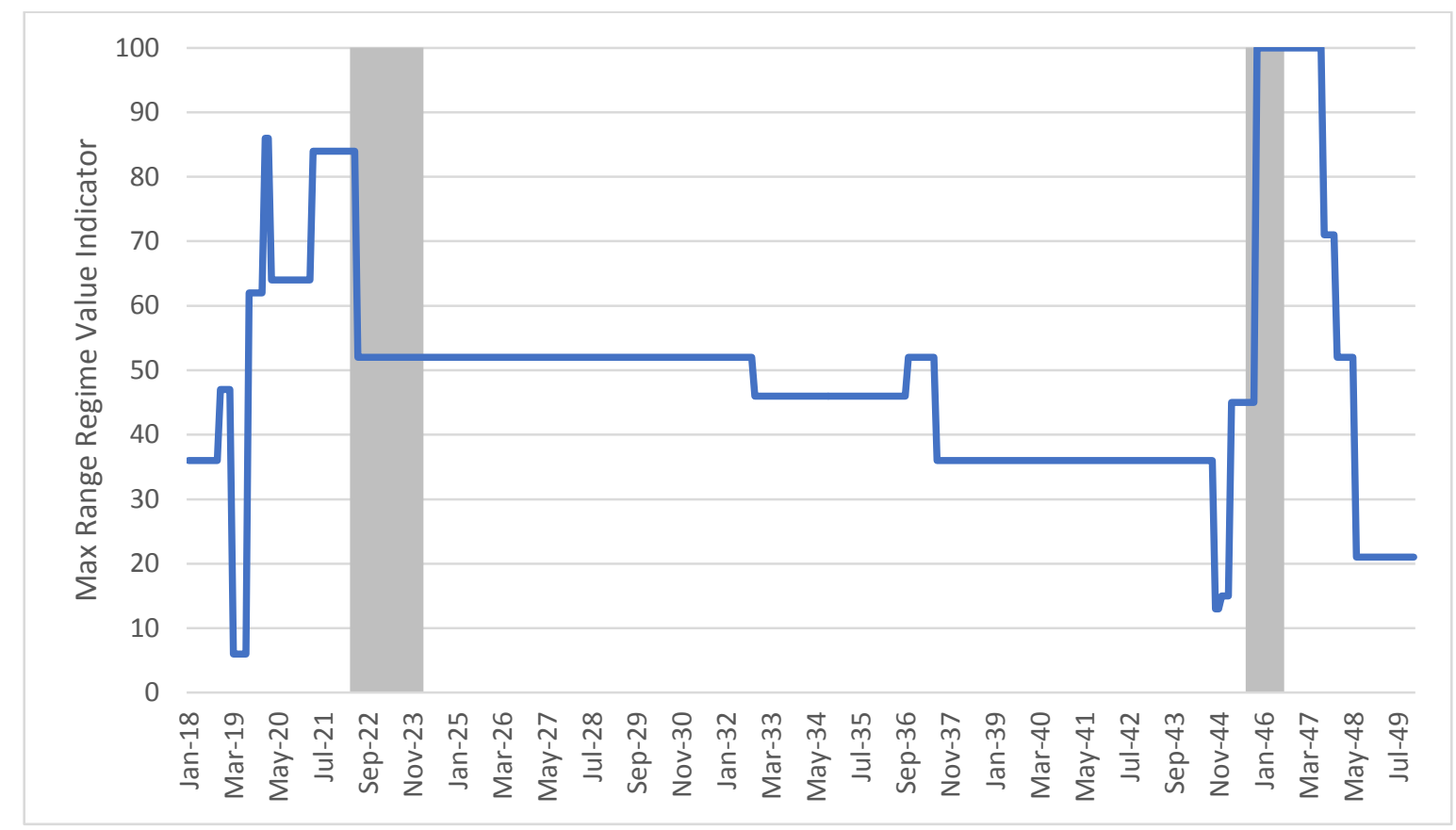

Source: Data from Rånge and Sandberg 2017. Shaded areas are hyperinflationary episodes.

access, encapsulating the checks and balances within a system, particular institutional arrangements, and political competition. 
This trend, of greater control of the economy by political institutions, was to continue and accelerate in the period after the hyperinflation. Paal (2000a:608), while not explicitly concerned with the institutional effects of the hyperinflation, makes this exact point, noting that "the economic policies followed during the stabilization also implied an ever-increasing government involvement in the economy." The coal mines of Hungary were nationalized at the end of June 1946, after the stabilization had been decided upon but before it was in place, and the end of 1946 saw nationalizations of the main industrial concerns with agitation for nationalization of the entire financial sector (Kenez 2006). Bomberger and Makinen (1980) also explicitly call our attention to the fact that the hyperinflation was supported by the Communist Party with a deeper goal, namely the destruction of the Hungarian middle class; this would be a necessary precursor to establishing an authoritarian left-wing government dominated by Moscow as well as a way to decimate many important economic institutions (such as private property). Such a shift in fundamental institutions was completed by 1950, following the Communist coup accomplished via the parliamentary elections of 1947.

\section{Conclusions}

This paper has examined the complexity of monetary policy but does so by situating monetary institutions and their actions within a broader institutional milieu. Using the examples of the Hungarian hyperinflations of 1923 and 1946, I have demonstrated how chaotic monetary policy, and especially hyperinflation, led directly to a shift of institutional paths. Whereas the Hungarian institutional system had been quietly authoritarian and with a modicum of state planning in the interwar period, the second hyperinflation broke the remaining economic institutions dedicated to a market economy and brought them under the control of the state. Seen from a complex adaptive perspective, the Communist takeover in Hungary was a shock to the institutional system, but one that had already been enabled by Hungary's democratic leaders years earlier.

The ramifications of this examination should be apparent, with an application to monetary policy similar to the insights of the original Lucas critique. In a world of quantitative easing and zero interest rates, unconventional monetary policy and more powerful central banks, the effects on the rest of the institutional system of a country can be dramatic. As happened in Europe in the 1930s or, as shown in this paper, in Hungary in 1946, there is a possibility that monetary policy at the extreme bound can unhinge the institutional paths of political institutions and shift their future functioning. Indeed, as I have hinted at, the Hungarian institutional path was not altered merely towards the communist takeover in 1947 but has changed the country over the longer-term. Echoes of the Hungarian hyperinflation from 1946 can be felt in today's modern Hungary, as populist leader Viktor Orbán has once again aggrandized power to the executive and slowly pulled it away from the market. Given that institutional effects have been shown in the literature to persist over decades or even centuries (Grosfeld and Zhuravskaya 2015), it is not surprising that the institutional path Hungary was put on as a result of $1945-46$ continues.

The policy lessons that emerge from a complexity approach to the institutional effects of hyperinflation are also rather radical, as they envisage creating another attractor apart from the pole of state intervention. As part of their analysis of monetary institutions (and using the continuum of efficient to resilient noted above), Lietaer et al. (2010) assert that national monetary systems, built on a monopoly of fiat money controlled by the government, are inherently brittle and have sacrificed resilience for 
efficiency. They suggest that competing (private) currencies help to improve the resilience of monetary systems, making them less prone to manipulation and preventing an institutional transfer of power as happened in Hungary. While merely a theoretical conjecture, such a reform would have decreased the ability of monetary policy to impact the entire institutional system of Hungary. Seen with a complexity lens, this is a reform which merits further examination, if only from the point of view of systemic stability.

\section{REFERENCES}

Adam, K., Evans, G. W., \& Honkapohja, S. (2006). Are hyperinflation paths learnable? Journal of Economic Dynamics and Control, 30(12), 2725-2748.

Akhmet, M., Akhmetova, Z., \& Fen, M. O. (2014). Chaos in economic models with exogenous shocks. Journal of Economic Behavior \& Organization, 106, 95-108.

Albin, P. S., \& Foley, D. K. (1998). Barriers and bounds to rationality: Essays on economic complexity and dynamics in interactive systems. Princeton, NJ: Princeton University Press.

Anderson, R. B., Bomberger, W. A., \& Makinen, G. E. (1988). The Demand for Money, the" Reform Effect," and the Money Supply Process in Hyperinflation: The Evidence from Greece and Hungary II Reexamined. Journal of Money, Credit and Banking, 20(4), 653-672.

Arthur, W. B. (2014). Complexity and the Economy. Oxford: Oxford University Press.

Arthur, W.B., Durlauf, S., and Lane, D. (1997). Introduction. In Arthur, W.B., Durlauf, S., and Lane, D. (eds)., The Economy as an Evolving Complex System II, Santa Fe Institute Studies in the Sciences of Complexity Vol. XXVII. New York: Addison-Wesley, pp. 1-14.

Barnett, W. A. \& Chen, P. (1988). The Aggregation-Theoretic Monetary Aggregates Are Chaotic and Have Strange Attractors: An Econometric Application of Mathematical Chaos. In W. Barnett, E. Berndt, and H. White (eds.), Dynamic Econometric Modeling. Cambridge: Cambridge University Press, pp.199-246.

Barnett, W. A., \& Serletis, A. (2000). Martingales, nonlinearity, and chaos. Journal of Economic Dynamics and Control, 24(5-7), 703-724.

Barucci, E. (2001). Fading memory learning in a class of forward-looking models with an application to hyperinflation dynamics. Economic Modelling, 18(2), 233-252.

Berend, I.T. (2001). Decades of Crisis: Central and Eastern Europe Before World War II. Berkeley: University of California Press.

Berry, B. J., \& Kim, H. (1997). Long Waves 1790-1990: Intermittency, Chaos, and Control. In Kiel, L.D., and Elliot, E. (eds.), Chaos theory in the social sciences: Foundations and Applications. Ann Arbor: University of Michigan Press, pp. 215-236.

Bittencourt, M. (2011). Inflation and financial development: Evidence from Brazil. Economic Modelling, 28(1-2), 91-99. 
Bomberger, W. A., \& Makinen, G. E. (1980). Indexation, inflationary finance, and hyperinflation: the 1945-1946 Hungarian experience. Journal of Political Economy, 88(3), 550-560.

(1983). The Hungarian hyperinflation and stabilization of 1945-1946. Journal of Political Economy, 91(5), 801-824.

Brock, A.W. \& Durlauf, S.N. (2006). Social interactions and macroeconomics. In Colander, D. (Ed.), PostWalrasian macroeconomics: Beyond the dynamic stochastic general equilibrium model. New York: Cambridge University Press, pp. 97-115.

Brock, W.A., Dechert, W.D. and Scheinkman, J.A. (1987). A Test for Independence Based on the Correlation Dimension. Department of Economics. University of Wisconsin at Madison, University of Houston, and University of Chicago.

Brock, W. A., Hsieh, D. A., LeBaron, B. D., \& Brock, W. E. (1991). Nonlinear dynamics, chaos, and instability: statistical theory and economic evidence. Cambridge, MA: MIT Press.

Brock, W. A., Scheinkman, J. A., Dechert, W. D., \& LeBaron, B. (1996). A test for independence based on the correlation dimension. Econometric Reviews, 15(3), 197-235.

Brooks, C. (1996). Testing for non-linearity in daily sterling exchange rates. Applied Financial Economics, 6(4), 307-317.

Burmeister, E., \& Wall, K. D. (1982). Kalman filtering estimation of unobserved rational expectations with an application to the German hyperinflation. Journal of Econometrics, 20(2), 255-284.

(1987). Unobserved Rational Expectations and the German Hyperinflation with Endogenous Money Supply. International Economic Review, 28(1), 15-32.

Cartledge, B. (2006). The Will to Survive: A History of Hungary. Middlesex, UK: Timewell Press.

Caves, R.E., Frankel, J.A., and Jones, R.W. (2006). World Trade and Payments: An Introduction. New York: Prentice Hall.

Colander, D. (1996). Beyond New Keynesian economics: Towards a post Walrasian macroeconomics. In R. Rotheim (Ed.), New Keynesian Economics/Post Keynesian Alternatives (pp. 277-287). London: Routledge.

Dahlberg, R. (2015). Resilience and complexity: Conjoining the discourses of two contested concepts. Culture Unbound: Journal of Current Cultural Research, 7(3), 541-557.

Davis, A.E. (2017). Money as a Social Institution: The Institutional Development of Capitalism. London: Routledge.

Day, R. H. (1994). Complex economic dynamics: an introduction to macroeconomic dynamics (Vol. 2). Cambridge, MA: MIT Press.

De Cecco, M. (1997). Central Banking in Central and Eastern Europe. Lessons from the Interwar Years' Experience. Rivista di storia economica, 1(1), 75-106 
DeCoster, G. P., \& Mitchell, D. W. (1991). Nonlinear monetary dynamics. Journal of Business \& Economic Statistics, 9(4), 455-461.

(1992). Dynamic implications of chaotic monetary policy. Journal of Macroeconomics, 14(2), 267-287.

DiMaggio, P. J., \& Powell, W. W. (Eds.). (1991). The New Institutionalism in Organizational Analysis (Vol. 17). Chicago: University of Chicago Press.

Dornbusch, R. (1992). Lessons from experiences with high inflation. The World Bank Economic Review, 6(1), 13-31.

Duit, A., \& Galaz, V. (2008). Governance and complexity-emerging issues for governance theory. Governance, 21(3), 311-335.

Durlauf, S. N. (2005). Complexity and empirical economics. The Economic Journal, 115(504).

(2012). Complexity, economics, and public policy. Politics, Philosophy \& Economics, 11(1), 45-75.

Dwyer, G. R. (1992). Stabilization policy can lead to chaos. Economic Inquiry, 30(1), 40-46.

Ecker-Racz, L. (1946). Hungarian Economic Developments, January 1945-June 1946. Budapest: U.S. Legation.

Engsted, T. (1998). Money demand during hyperinflation: Cointegration, rational expectations, and the importance of money demand shocks. Journal of Macroeconomics, 20(3), 533-552.

Feinstein, C. H., Temin, P., \& Toniolo, G. (2008). The World Economy Between the World Wars. Oxford: Oxford University Press.

Fernández-Rodriguez, F., Sosvilla-Rivero, S., \& Andrada-Felix, J. (2005). Testing chaotic dynamics via Lyapunov exponents. Journal of Applied Econometrics, 20(7), 911-930.

Friedman, M. (1953). The effects of a full-employment policy on economic stability: A formal analysis. In Essays in Positive Economics. Chicago: University of Chicago Press, pp. 117-132.

(1961). The lag in effect of monetary policy. Journal of Political Economy, 69(5), 447-466.

George, D., \& Oxley, L. (1999). Robustness and local linearisation in economic models. Journal of Economic Surveys, 13(5), 529-550.

Grassberger, P., \& Procaccia, I. (1983). Measuring the strangeness of strange attractors. Physica D: Nonlinear Phenomena, 9(1-2), 189-208.

Grosfeld, I., \& Zhuravskaya, E. (2015). Cultural vs. economic legacies of empires: Evidence from the partition of Poland. Journal of Comparative Economics, 43(1), 55-75.

Grossman, P. Z., \& Horváth, J. (2000). The Dynamics of Hungarian Hyperinflation 1945-46: a New Perspective. Journal of European Economic History, 29(2), 405.

Hartwell, C.A. (2017). Understanding "Development": Insights from Some Aspects of Complexity Theory. Homo Oeconomicus, 34(2-3), 165-190. 
(2018). The "Hierarchy of Institutions" reconsidered: Monetary policy and its effect on the rule of law in interwar Poland. Explorations in Economic History, https://doi.org/10.1016/j.eeh.2018.03.001.

Hayek, F. A. (1945). The use of knowledge in society. American Economic Review, 35(4), 519-530.

Hercowitz, Z. (1981). Money and the dispersion of relative prices. Journal of Political Economy, 89(2), 328-356.

James, H. (1992). Financial flows across frontiers during the interwar depression. The Economic History Review, 45(3), 594-613.

Kelsey, D. (1988). The economics of chaos or the chaos of economics. Oxford Economic Papers, 40(1), 131.

Kenez, P. (2006). Hungary from the Nazis to the Soviets: The Establishment of the Communist Regime in Hungary, 1944-1948. Cambridge: Cambridge University Press.

Kirman, A. (2009). Complexity and aggregation. In Rosser, J. B. (ed.), Handbook of Research on Complexity. London: Edward Elgar Publishing, pp. 171-194.

Kočenda, E. (2001). An alternative to the BDS test: integration across the correlation integral. Econometric Reviews, 20(3), 337-351.

Koyama, M., \& Johnson, B. (2015). Monetary stability and the rule of law. Journal of Financial Stability, 17, 46-58.

Leijonhufvud, A. (1993). Towards a not-too-rational macroeconomics. Southern Economic Journal, 1-13.

(1997). Macroeconomics and complexity: inflation theory In Arthur, W.B., Durlauf, S., and Lane, D. (eds)., The Economy as an Evolving Complex System II, Santa Fe Institute Studies in the Sciences of Complexity Vol. XXVII. New York: Addison-Wesley, pp. 321-336.

Lindgren, K. (1991). Evolutionary Phenomena in Simple Dynamics. In Langton, C., Taylor, C., Farmer, J.D., and Rasmussen, S. (eds.), Artificial Life II. Reading, MA: Addison-Wesley, pp. 295-312.

Lopez, J. A., \& Mitchener, K. J. (2018). Uncertainty and Hyperinflation: European Inflation Dynamics after World War I (No. w24624). National Bureau of Economic Research.

Lynsky, M. (1934). The Bounty and Processing Tax on Wheat in Hungary. Journal of Farm Economics, 16(3), 387-409.

Macher, F. (2015). Did Monetary Forces Cause the Hungarian Crises of 1931? EHES Working papers in Economic History, no. 86, October.

Maiwald, T., Mammen, E., Nandi, S., \& Timmer, J. (2008). Surrogate data-A qualitative and quantitative analysis. In Dahlhaus, R., Kurths, J., Maass, P., and Timmer, J. (eds.), Mathematical Methods in Signal Processing and Digital Image Analysis. Springer: Berlin, pp. 41-74.

Marcet, A., \& Nicolini, J. P. (2003). Recurrent hyperinflations and learning. American Economic Review, 93(5), 1476-1498. 
Marcet, A., \& Sargent, T. (1989). Least-squares learning and the dynamics of hyperinflation. In Barnett, W.A., Geweke, J., \& Shell, K. (eds.), Economic Complexity: Chaos, Sun spots, Bubbles, and Nonlinearity. Cambridge: Cambridge University Press, pp. 119-140.

Marimon, R., McGrattan, E., \& Sargent, T. J. (1990). Money as a medium of exchange in an economy with artificially intelligent agents. Journal of Economic Dynamics and Control, 14(2), 329-373.

Marmefelt, T. (2015). Interwar Monetary Fragmentation and the Gold Standard Restored: The Crisis of 1929 Compared with the Crisis of 2008. Paper prepared for the International Conference on Large-Scale Crises: 1929 vs. 2008, Ancona, December 17-19, 2015, available at https://www.researchgate.net/profile/Thomas Marmefelt/publication/308118467 Interwar Monetary Fragmentation and the Gold Standard Restored The Crisis of 1929 Compared with the Crisis of 2008/links/57da954d08ae72d72ea355f8/Interwar-Monetary-Fragmentation-and-the-Gold-StandardRestored-The-Crisis-of-1929-Compared-with-the-Crisis-of-2008.pdf.

Martin, A., \& Moon, P. (1992). Purchasing decisions, partial knowledge, and economic search experimental and simulation evidence. Journal of Behavioral Decision Making, 5(4), 253-266.

Mitchell, B. R. (1992). International Historical Statistics: Europe 1750-1988. New York: Stockton Press.

Mizuno, T., Takayasu, M., \& Takayasu, H. (2002). The mechanism of double-exponential growth in hyperinflation. Physica A: Statistical Mechanics and its Applications, 308(1-4), 411-419.

Mohseni, R.M., Zhang, W., \& Cao, J. (2015). Chaotic Behavior in Monetary Systems: Comparison among Different Types of Taylor Rules. International Journal of Social, Behavioral, Educational, Economic and Management Engineering, 9(8), 2316-2319.

Nogaro, B. (1948). Hungary's recent monetary Crisis and its Theoretical Meaning. The American Economic Review, 38(4), 526-542.

Overy, R.J. (1996). The Nazi Economic Recovery 1932-1938. Cambridge: Cambridge University Press.

Paal, B. (2000a). Destabilizing effects of a successful stabilization: a forward-looking explanation of the second Hungarian hyperinflation. Economic Theory, 15(3), 599-630.

(2000b). Measuring the Inflation of Parallel Currencies: An Empirical Reevaluation of the Second Hungarian Hyperinflation. Stanford Institute for Economic Policy Research (SIEPR) Discussion Paper No. 00-01, June.

Pastor Jr, M. (1991). Bolivia: Hyperinflation, stabilisation, and beyond. The Journal of Development Studies, 27(2), 211-237.

Payne, J.M, \& Bettman, J.R. (2002). Preferential Choice and Adaptive Strategy Use. In Gigerenzer, G., and Selten, R. (eds.), Bounded Rationality: The Adaptive Toolbox. Cambridge, MA: MIT Press, pp. 123-146.

Peel, D. A., \& Yadav, P. (1995). The time series behaviour of spot exchange rates in the German hyperinflation period: (Was the process chaotic?). Empirical Economics, 20(3), 455-471.

Peterecz, Z. (2013). Jeremiah Smith Jr. and Hungary, 1924-1926: the United States, the League of Nations, and the Financial Reconstruction of Hungary. Berlin: Walter de Gruyter. 
Pogány, Á. (2015). Crisis Management Strategies after World War I: The Case of the Budapest Flour Mills. The Hungarian Historical Review, 868-899.

Ramsey J.B. (1990) Economic and Financial Data as Nonlinear Processes. I: Dwyer G.P. \& Hafer R.W. (eds.), The Stock Market: Bubbles, Volatility, and Chaos. Dordrecht: Springer, pp. 81-134.

Rånge, M., \& Sandberg, M. (2017). Political Institutions and Regimes since 1600: A New Historical Data Set. Journal of Interdisciplinary History, 47(4), 495-520.

Rao, P. (2011). Chaos Models and the Monetary Dynamics of Hyperinflation. The International Business \& Economics Research Journal (Online), 10(11), 109-118.

Rosser Jr, J. B. (1996). Chaos theory and post Walrasian macroeconomics. In Colander, D. (ed.), Beyond Micro foundations: Post-Walrasian Economics. Cambridge: Cambridge University Press, pp. 87-107.

(1999). On the complexities of complex economic dynamics.Journal of Economic Perspectives, 13(4), 169-192.

Rosser Jr, J. B., \& Rosser, M. V. (1997). Complex dynamics and systemic change: how things can go very wrong. Journal of Post Keynesian Economics, 20(1), 103-122.

Salies, E., \& Moffatt, P. (2006). Inaccurate approximations in the modeling of hyper-inflations. Economics Bulletin, 28(1).

Sargent, T.J. (1983). The Ends of Four Big Inflations. In Hall, R. (ed.), Inflation: Causes and Effects. Chicago: University of Chicago Press, pp. 41-98.

Sargent, T. J., \& Wallace, N. (1973). Rational expectations and the dynamics of hyperinflation. International Economic Review, 14(2), 328-350.

Serletis, A. (1995). Random walks, breaking trend functions, and the chaotic structure of the velocity of money. Journal of Business \& Economic Statistics, 13(4), 453-465.

Shubik, M. (1971). A theory of money and financial institutions: Fiat money and noncooperative equilibrium in a closed economy. International Journal of Game Theory, 1(1), 243-268.

(1997). Time and Money. In Arthur, W.B., Durlauf, S., and Lane, D. (eds)., The Economy as an Evolving Complex System II, Santa Fe Institute Studies in the Sciences of Complexity Vol. XXVII. New York: Addison-Wesley, pp. 263-283.

Siklos, P.L. (1990). War Finance, Reconstruction, Hyperinflation and Stabilization in Hungary, 1938-48. New York: Palgrave Macmillan.

(1991a). The money growth-inflation relationship under hyperinflation: an illustration from Hungary's postwar experience. Applied Economics, 23(9), 1453-1460.

(1991b). Fiscal Policy and Inflationary Expectations: The Hungarian Tax Pengö Experiment of 1946. Journal of European Economic History, 20(3), 615-628.

Simmons, B. A. (1996). Rulers of the game: central bank independence during the interwar years. International Organization, 50(3), 407-443. 
Soliman, A. S. (1996). Transitions from stable equilibrium points to periodic cycles to chaos in a Philips curve system. Journal of Macroeconomics, 18(1), 139-153.

Solomon, T. H., \& Solomon, E. H. (1991). Money Stability and Control: The Perverse Effects of Feedback Loops. In Solomon, E.H. (ed.), Electronic Money Flows: The Molding of a New Financial Order. Dordrecht: Springer, pp. 89-108.

Sornette, D., Takayasu, H., \& Zhou, W. X. (2003). Finite-time singularity signature of hyperinflation. Physica A: Statistical Mechanics and its Applications, 325(3-4), 492-506.

Starr, R.M. (2010). Money: In Transactions and Finance. In Majumdar, M., Wills, I., Sgro, P.M., and Gowd, J.M. (eds.), Fundamental Economics - Volume I. Paris: Eolss Publishing, pp. 270-299.

Stutzer, M. J. (1980). Chaotic dynamics and bifurcation in a macro model. Journal of Economic Dynamics and Control, 2, 353-376.

Szybisz, M. A., \& Szybisz, L. (2009). Finite-time singularities in the dynamics of hyperinflation in an economy. Physical Review E, 80(2), 026116.

(2017). Extended nonlinear feedback model for describing episodes of high inflation. Physica A: Statistical Mechanics and its Applications, 465, 91-108.

Theiler, J., Eubank, S., Longtin, A., Galdrikian, B., \& Farmer, J. D. (1992). Testing for nonlinearity in time series: the method of surrogate data. Physica D: Nonlinear Phenomena, 58(1-4), 77-94.

Végh, C. A. (1992). Stopping high inflation: an analytical overview. IMF Staff Papers, 39(3), 626-695.

White, W. R. (2017). Conducting Monetary Policy in a Complex, Adaptive Economy: Past Mistakes and Future Possibilities. Credit and Capital Markets-Kredit und Kapital, 50(2), 213-235.

Wolf, A., Swift, J. B., Swinney, H. L., \& Vastano, J. A. (1985). Determining Lyapunov exponents from a time series. Physica D: Nonlinear Phenomena, 16(3), 285-317.

Wolf, N. (2010). Europe's great depression: coordination failure after the first world war. Oxford Review of Economic Policy, 26(3), 339-369. 
Table 1 - Results of BDS Tests on Hungarian Monetary Variables, 1923 Hyperinflation

\begin{tabular}{|c|c|c|c|c|c|c|c|c|c|c|c|c|}
\hline \multirow[b]{2}{*}{$\mathbf{m}$} & \multicolumn{3}{|c|}{$\varepsilon=0.5$} & \multicolumn{3}{|c|}{$\varepsilon=1.0$} & \multicolumn{3}{|c|}{$\varepsilon=1.5$} & \multicolumn{3}{|c|}{$\varepsilon=2.0$} \\
\hline & BDS & z-statistic & $\begin{array}{l}\text { Bootstrapped } \\
\text { p-value }\end{array}$ & BDS & z-statistic & $\begin{array}{c}\text { Bootstrapped } \\
\text { p-value }\end{array}$ & BDS & z-statistic & $\begin{array}{c}\text { Bootstrapped } \\
\text { p-value }\end{array}$ & BDS & z-statistic & $\begin{array}{c}\text { Bootstrapped } \\
\text { p-value }\end{array}$ \\
\hline 2 & 0.079 & 9.930 & $0.000 * * *$ & 0.085 & 9.320 & $0.000 * * *$ & 0.049 & 6.095 & $0.000 * * *$ & 0.011 & 2.434 & $0.078^{*}$ \\
\hline 3 & 0.089 & 12.051 & $0.000 * * *$ & 0.131 & 10.444 & $0.000 * * *$ & 0.098 & 7.104 & $0.000 * * *$ & 0.031 & 3.351 & $0.017^{* *}$ \\
\hline 4 & 0.079 & 15.346 & $0.000 * * *$ & 0.152 & 11.592 & $0.000 * * *$ & 0.134 & 7.562 & $0.000 * * *$ & 0.053 & 3.874 & $0.005^{* * *}$ \\
\hline 5 & 0.066 & 20.693 & $0.000 * * *$ & 0.161 & 13.517 & $0.000 * * *$ & 0.158 & 7.956 & $0.000 * * *$ & 0.073 & 4.095 & $0.004 * * *$ \\
\hline
\end{tabular}

\begin{tabular}{|c|c|c|c|c|c|c|c|c|c|c|c|c|}
\hline \multicolumn{13}{|c|}{ Change in Exchange Rate, 1922-25 } \\
\hline & \multicolumn{3}{|c|}{$\varepsilon=0.5$} & \multicolumn{3}{|c|}{$\varepsilon=1.0$} & \multicolumn{3}{|c|}{$\varepsilon=1.5$} & \multicolumn{3}{|c|}{$\varepsilon=2.0$} \\
\hline $\mathbf{m}$ & BDS & z-statistic & $\begin{array}{l}\text { Bootstrapped } \\
\text { p-value }\end{array}$ & BDS & z-statistic & $\begin{array}{c}\text { Bootstrapped } \\
\text { p-value }\end{array}$ & BDS & z-statistic & $\begin{array}{c}\text { Bootstrapped } \\
\text { p-value }\end{array}$ & BDS & z-statistic & $\begin{array}{l}\text { Bootstrapped } \\
\text { p-value }\end{array}$ \\
\hline 2 & 0.101 & 10.373 & $0.000 * * *$ & 0.046 & 6.251 & $0.000 * * *$ & 0.025 & 6.179 & $0.004 * * *$ & 0.013 & 4.173 & $0.022^{* *}$ \\
\hline 3 & 0.152 & 12.154 & $0.000 * * *$ & 0.086 & 6.396 & $0.000 * * *$ & 0.047 & 5.660 & $0.002 * * *$ & 0.025 & 3.702 & $0.027^{* *}$ \\
\hline 4 & 0.173 & 14.355 & $0.000 * * *$ & 0.126 & 6.805 & $0.000 * * *$ & 0.067 & 5.224 & $0.002 * * *$ & 0.037 & 3.408 & $0.030 * *$ \\
\hline 5 & 0.185 & 18.098 & $0.000 * * *$ & 0.154 & 6.869 & $0.000 * * *$ & 0.083 & 4.773 & $0.002 * * *$ & 0.047 & 3.085 & $0.037^{* *}$ \\
\hline
\end{tabular}

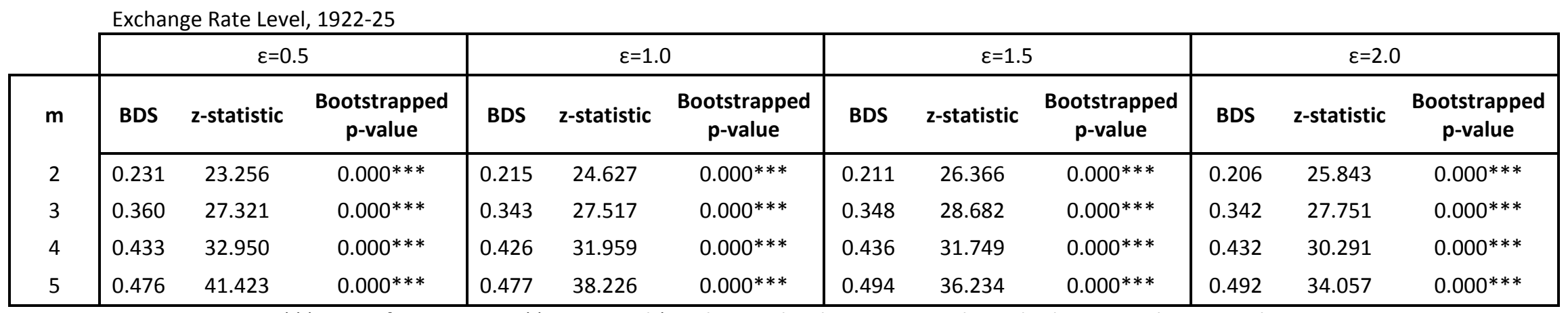

Note: ${ }^{* * *}$ is significance at $1 \%,{ }^{* *}$ at $5 \%$, and ${ }^{*}$ at the $10 \%$ level. Bootstrapped standard errors with 5000 replications. 


\section{Table 1 continued}

Percentage growth of bills in circulation, 1922-38

\begin{tabular}{|c|c|c|c|c|c|c|c|c|c|c|c|c|}
\hline \multirow[b]{2}{*}{ m } & \multicolumn{3}{|c|}{$\varepsilon=0.5$} & \multicolumn{3}{|c|}{$\varepsilon=1.0$} & \multicolumn{3}{|c|}{$\varepsilon=1.5$} & \multicolumn{3}{|c|}{$\varepsilon=2.0$} \\
\hline & BDS & z-statistic & $\begin{array}{l}\text { Bootstrapped } \\
\text { p-value }\end{array}$ & BDS & z-statistic & $\begin{array}{l}\text { Bootstrapped } \\
\text { p-value }\end{array}$ & BDS & z-statistic & $\begin{array}{c}\text { Bootstrapped } \\
\text { p-value }\end{array}$ & BDS & z-statistic & $\begin{array}{c}\text { Bootstrapped } \\
\text { p-value }\end{array}$ \\
\hline 2 & 0.0239 & 3.7189 & $0.0008 * * *$ & 0.014 & 2.274 & $0.044 * *$ & 0.011 & 2.873 & $0.041^{* *}$ & 0.012 & 4.666 & $0.009 * * *$ \\
\hline 3 & 0.0427 & 5.4514 & $0.000 * * *$ & 0.037 & 3.432 & $0.004^{* * *}$ & 0.034 & 4.327 & $0.003 * * *$ & 0.029 & 5.492 & $0.002 * * *$ \\
\hline 4 & 0.0476 & 6.6453 & $0.000 * * *$ & 0.056 & 3.836 & $0.002 * * *$ & 0.054 & 4.477 & $0.000 * * *$ & 0.045 & 5.343 & $0.002 * * *$ \\
\hline 5 & 0.0463 & 8.0732 & $0.000 * * *$ & 0.073 & 4.204 & $0.000 * * *$ & 0.073 & 4.511 & $0.000 * * *$ & 0.063 & 5.345 & $0.002 * * *$ \\
\hline
\end{tabular}

Note: $* * *$ is significance at $1 \%, * *$ at $5 \%$, and $*$ at the $10 \%$ level. Bootstrapped standard errors with 5000 replications. 
Table 2 - Results of BDS Tests on Hungarian Monetary Variables, 1946 Hyperinflation

\begin{tabular}{|c|c|c|c|c|c|c|c|c|c|c|c|c|}
\hline \multirow[b]{2}{*}{ m } & \multicolumn{3}{|c|}{$\varepsilon=0.5$} & \multicolumn{3}{|c|}{$\varepsilon=1.0$} & \multicolumn{3}{|c|}{$\varepsilon=1.5$} & \multicolumn{3}{|c|}{$\varepsilon=2.0$} \\
\hline & BDS & z-statistic & $\begin{array}{l}\text { Bootstrapped } \\
\text { p-value }\end{array}$ & BDS & z-statistic & $\begin{array}{c}\text { Bootstrapped } \\
\text { p-value }\end{array}$ & BDS & z-statistic & $\begin{array}{c}\text { Bootstrapped } \\
\text { p-value }\end{array}$ & BDS & z-statistic & $\begin{array}{c}\text { Bootstrapped } \\
\text { p-value }\end{array}$ \\
\hline 2 & 0.160 & 14.345 & $0.000 * * *$ & 0.152 & 16.223 & $0.000 * * *$ & 0.092 & 14.841 & $0.000 * * *$ & 0.000 & 0.105 & 0.418 \\
\hline 3 & 0.263 & 15.477 & $0.000 * * *$ & 0.260 & 16.188 & $0.000 * * *$ & 0.182 & 15.461 & $0.000 * * *$ & 0.004 & 1.194 & 0.353 \\
\hline 4 & 0.328 & 16.891 & $0.000 * * *$ & 0.336 & 16.187 & $0.000 * * *$ & 0.249 & 14.865 & $0.000 * * *$ & 0.008 & 1.344 & 0.340 \\
\hline 5 & 0.369 & 18.943 & $0.000 * * *$ & 0.397 & 16.902 & $0.000 * * *$ & 0.324 & 15.597 & $0.000 * * *$ & 0.020 & 2.374 & 0.216 \\
\hline
\end{tabular}

\begin{tabular}{|c|c|c|c|c|c|c|c|c|c|c|c|c|}
\hline \multirow[b]{2}{*}{ m } & \multicolumn{3}{|c|}{$\varepsilon=0.5$} & \multicolumn{3}{|c|}{$\varepsilon=1.0$} & \multicolumn{3}{|c|}{$\varepsilon=1.5$} & \multicolumn{3}{|c|}{$\varepsilon=2.0$} \\
\hline & BDS & z-statistic & $\begin{array}{l}\text { Bootstrapped } \\
\text { p-value }\end{array}$ & BDS & z-statistic & $\begin{array}{l}\text { Bootstrapped } \\
\text { p-value }\end{array}$ & BDS & z-statistic & $\begin{array}{l}\text { Bootstrapped } \\
\text { p-value }\end{array}$ & BDS & z-statistic & $\begin{array}{l}\text { Bootstrapped } \\
\text { p-value }\end{array}$ \\
\hline 2 & 0.242 & 26.857 & $0.000 * * *$ & 0.203 & 20.148 & $0.000 * * *$ & 0.152 & 17.617 & $0.000 * * *$ & 0.115 & 17.031 & $0.000 * * *$ \\
\hline 3 & 0.360 & 35.375 & $0.000^{* * *}$ & 0.338 & 21.411 & $0.000 * * *$ & 0.262 & 17.021 & $0.000 * * *$ & 0.200 & 15.527 & $0.000^{* * *}$ \\
\hline 4 & 0.417 & 48.503 & $0.000 * * *$ & 0.428 & 23.151 & $0.000 * * *$ & 0.342 & 16.618 & $0.000 * * *$ & 0.262 & 14.237 & $0.000 * * *$ \\
\hline 5 & 0.446 & 69.875 & $0.000 * * *$ & 0.489 & 25.806 & $0.000 * * *$ & 0.401 & 16.617 & $0.000 * * *$ & 0.306 & 13.291 & $0.000 * * *$ \\
\hline
\end{tabular}

\begin{tabular}{|c|c|c|c|c|c|c|c|c|c|c|c|c|}
\hline \multirow[b]{2}{*}{ m } & \multicolumn{3}{|c|}{$\varepsilon=0.5$} & \multicolumn{3}{|c|}{$\varepsilon=1.0$} & \multicolumn{3}{|c|}{$\varepsilon=1.5$} & \multicolumn{3}{|c|}{$\varepsilon=2.0$} \\
\hline & BDS & z-statistic & $\begin{array}{l}\text { Bootstrapped } \\
\text { p-value }\end{array}$ & BDS & z-statistic & $\begin{array}{c}\text { Bootstrapped } \\
p \text {-value }\end{array}$ & BDS & z-statistic & $\begin{array}{l}\text { Bootstrapped } \\
\text { p-value }\end{array}$ & BDS & z-statistic & $\begin{array}{l}\text { Bootstrapped } \\
\text { p-value }\end{array}$ \\
\hline 2 & 0.061 & 8.632 & $0.000 * * *$ & 0.028 & 6.068 & $0.001 * * *$ & 0.024 & 7.851 & $0.000^{* * *}$ & 0.024 & 8.635 & $0.000^{* * *}$ \\
\hline 3 & 0.088 & 8.319 & $0.000 * * *$ & 0.045 & 4.858 & $0.002^{* * *}$ & 0.046 & 7.089 & $0.001^{* * *}$ & 0.046 & 7.810 & $0.000 * * *$ \\
\hline 4 & 0.102 & 8.695 & $0.000 * * *$ & 0.071 & 5.104 & $0.000 * * *$ & 0.067 & 6.444 & $0.001^{* * *}$ & 0.068 & 7.076 & $0.000 * * *$ \\
\hline 5 & 0.099 & 8.652 & $0.000 * * *$ & 0.085 & 4.639 & $0.001 * * *$ & 0.087 & 5.936 & $0.001 * * *$ & 0.089 & 6.511 & $0.000 * * *$ \\
\hline
\end{tabular}


Table 2 continued

\begin{tabular}{|c|c|c|c|c|c|c|c|c|c|c|c|c|}
\hline & \multicolumn{3}{|c|}{$\varepsilon=0.5$} & \multicolumn{3}{|c|}{$\varepsilon=1.0$} & \multicolumn{3}{|c|}{$\varepsilon=1.5$} & \multicolumn{3}{|c|}{$\varepsilon=2.0$} \\
\hline $\mathbf{m}$ & BDS & z-statistic & $\begin{array}{l}\text { Bootstrapped } p- \\
\text { value }\end{array}$ & BDS & z-statistic & $\begin{array}{c}\text { Bootstrapped } \\
\text { p-value }\end{array}$ & BDS & z-statistic & $\begin{array}{c}\text { Bootstrapped } \\
\text { p-value }\end{array}$ & BDS & z-statistic & $\begin{array}{l}\text { Bootstrapped } \\
\text { p-value }\end{array}$ \\
\hline 2 & 0.145 & 12.971 & $0.000 * * *$ & 0.099 & 11.852 & $0.000 * * *$ & 0.074 & 10.909 & $0.000 * * *$ & 0.063 & 10.578 & $0.000 * * *$ \\
\hline 3 & 0.250 & 12.352 & $0.000 * * *$ & 0.170 & 10.403 & $0.000 * * *$ & 0.123 & 8.968 & $0.000 * * *$ & 0.103 & 8.380 & $0.000 * * *$ \\
\hline 4 & 0.326 & 11.877 & $0.000 * * *$ & 0.218 & 9.141 & $0.000 * * *$ & 0.150 & 7.265 & $0.000 * * *$ & 0.121 & 6.434 & $0.000 * * *$ \\
\hline 5 & 0.381 & 11.684 & $0.000 * * *$ & 0.248 & 8.116 & $0.000 * * *$ & 0.158 & 5.792 & $0.000 * * *$ & 0.119 & 4.749 & $0.000 * * *$ \\
\hline
\end{tabular}

\begin{tabular}{|c|c|c|c|c|c|c|c|c|c|c|c|c|}
\hline \multirow[b]{2}{*}{ m } & \multicolumn{3}{|c|}{$\varepsilon=0.5$} & \multicolumn{3}{|c|}{$\varepsilon=1.0$} & \multicolumn{3}{|c|}{$\varepsilon=1.5$} & \multicolumn{3}{|c|}{$\varepsilon=2.0$} \\
\hline & BDS & z-statistic & $\begin{array}{l}\text { Bootstrapped } p- \\
\text { value }\end{array}$ & BDS & z-statistic & $\begin{array}{l}\text { Bootstrapped } \\
\text { p-value }\end{array}$ & BDS & z-statistic & $\begin{array}{l}\text { Bootstrapped } \\
\text { p-value }\end{array}$ & BDS & z-statistic & $\begin{array}{l}\text { Bootstrapped } \\
\text { p-value }\end{array}$ \\
\hline 2 & 0.164 & 15.653 & $0.000 * * *$ & 0.152 & 16.298 & $0.000 * * *$ & 0.136 & 16.906 & $0.000 * * *$ & 0.094 & 15.250 & $0.000 * * *$ \\
\hline 3 & 0.268 & 19.068 & $0.000 * * *$ & 0.254 & 16.704 & $0.000 * * *$ & 0.239 & 16.905 & $0.000 * * *$ & 0.190 & 16.342 & $0.000 * * *$ \\
\hline 4 & 0.338 & 23.810 & $0.000 * * *$ & 0.334 & 18.097 & $0.000 * * *$ & 0.321 & 17.349 & $0.000 * * *$ & 0.267 & 16.328 & $0.000 * * *$ \\
\hline 5 & 0.379 & 30.161 & $0.000 * * *$ & 0.389 & 19.764 & $0.000 * * *$ & 0.384 & 18.040 & $0.000 * * *$ & 0.338 & 16.731 & $0.000 * * *$ \\
\hline
\end{tabular}

\begin{tabular}{|c|c|c|c|c|c|c|c|c|c|c|c|c|}
\hline \multirow[b]{2}{*}{ m } & \multicolumn{3}{|c|}{$\varepsilon=0.5$} & \multicolumn{3}{|c|}{$\varepsilon=1.0$} & \multicolumn{3}{|c|}{$\varepsilon=1.5$} & \multicolumn{3}{|c|}{$\varepsilon=2.0$} \\
\hline & BDS & z-statistic & $\begin{array}{l}\text { Bootstrapped } p \text { - } \\
\text { value }\end{array}$ & BDS & z-statistic & $\begin{array}{l}\text { Bootstrapped } \\
\text { p-value }\end{array}$ & BDS & z-statistic & $\begin{array}{l}\text { Bootstrapped } \\
\text { p-value }\end{array}$ & BDS & z-statistic & $\begin{array}{l}\text { Bootstrapped } \\
\text { p-value }\end{array}$ \\
\hline 2 & 0.243 & 29.747 & $0.000 * * *$ & 0.214 & 24.103 & $0.000 * * *$ & 0.166 & 21.888 & $0.000 * * *$ & 0.127 & 20.203 & $0.000 * * *$ \\
\hline 3 & 0.360 & 39.705 & $0.000 * * *$ & 0.352 & 26.365 & $0.000 * * *$ & 0.288 & 21.783 & $0.000 * * *$ & 0.225 & 19.008 & $0.000 * * *$ \\
\hline 4 & 0.416 & 55.187 & $0.000 * * *$ & 0.443 & 29.341 & $0.000 * * *$ & 0.377 & 21.914 & $0.000 * * *$ & 0.299 & 18.009 & $0.000 * * *$ \\
\hline 5 & 0.444 & 80.646 & $0.000 * * *$ & 0.504 & 33.677 & $0.000 * * *$ & 0.444 & 22.595 & $0.000 * * *$ & 0.356 & 17.436 & $0.000^{* * *}$ \\
\hline
\end{tabular}

Note: ${ }^{* * *}$ is significance at $1 \%, * *$ at $5 \%$, and $*$ at the $10 \%$ level. Bootstrapped standard errors with 5000 replications. 
Table 3 - Maximum Lyapunov Exponents (MLE) and Significance for Hungarian Monetary Variables

\begin{tabular}{|c|c|c|c|}
\hline 1923 & MLE & Bootstrapped CV & p-value \\
\hline Change in the Exchange Rate Index, 1922-25 & 0.019 & 0.012 & 0.110 \\
\hline Change in the Exchange Rate, 1922-25 & 0.030 & 0.017 & $0.008 * * *$ \\
\hline Exchange Rate Level, 1922-25 & 0.115 & 0.145 & 0.115 \\
\hline $\begin{array}{l}\text { Percentage growth of notes in circulation, 1922- } \\
1938\end{array}$ & 0.012 & 0.009 & $0.016^{* *}$ \\
\hline
\end{tabular}

\begin{tabular}{|c|c|c|c|}
\hline 1946 & MLE & Bootstrapped CV & p-value \\
\hline Growth of daily "Cost of Living Index" 1946 & 0.061 & 0.085 & 0.120 \\
\hline Log of daily "Cost of Living Index" 1946 & 0.019 & 0.054 & 0.467 \\
\hline Change in daily exchange rate, $1945-46$ & 0.042 & 0.027 & $0.023^{* *}$ \\
\hline Daily exchange rate level, 1945-46 & 0.060 & 0.098 & 0.774 \\
\hline Growth of the tax pengo price index, daily, 1946 & 0.019 & 0.032 & 0.644 \\
\hline $\begin{array}{l}\text { Log of the level of tax pengo price index, daily, } \\
1946\end{array}$ & 0.011 & 0.039 & 0.327 \\
\hline
\end{tabular}

Note: ${ }^{* * *}$ is significance at $1 \%,{ }^{* *}$ at $5 \%$, and ${ }^{*}$ at the $10 \%$ level. Bootstrapped standard errors with 1000 replications. 


\section{DATA APPENDIX}

The various underlying series for the BDS and the Lyapunov exponent calculations shown in Section IV came from different sources, some secondary and some primary, some previously compiled and some never before available in electronic form.

\section{3}

Levels of and change in the monthly exchange rate: As stated, this metric is both the level and the change in level month-on-month of the Hungarian korona versus the Swiss franc from January 1914 to December 1926. The data was collected from various hard-copy volumes of Magyar Statisztikai Évkönyv (Hungarian Statistical Yearbook) published by the Hungarian National Statistical Office from 1923 to 1927 and is (to my knowledge) the first time that this data has been digitized.

Levels of and change in the monthly exchange rate index of Hungarian currency movements: The Magyar Statisztikai Évkönyv also published a series of exchange rate indexes to track the value of the korona from January 1914 to December 1925. The index covers the value of the gold crown until June 1924 at the rate of parity in Zürich and New York, then shifts in July 1924 to encompass the central rate versus the US dollar in Budapest. This series was apparently abandoned after December 1925. Again, this is the first time that this series has been available electronically.

Percentage growth of bills in circulation, 1922-1938: This data series is a true innovation in the examination of monetary dynamics in Hungary, as it examines the actual number of banknotes in circulation rather than their value (which is the standard for examining Hungary's hyperinflations). Collated and entered into spreadsheets manually, the source data is the various hard copy volumes of the Magyar Statisztikai Évkönyv from 1923 to 1948. The data series breaks at December 1938 and is absent again until immediately post-stabilization in August 1946, and searches of historical archives to this point have been fruitless in finding this missing data (again, most sources available quote the value of money in circulation). Finally, rather than use the log change to approximate growth, I have shifted to using percentage change as it is a more accurate indicator of inflation of the number of bills in circulation. As Salies and Moffatt (2006) correctly note, log approximations are effective only when changes are small, which is demonstrably not the case in a hyperinflation, and thus the percentage change is used instead.

\section{6}

Level (in logs) and growth of the daily "Cost of Living Index": Taken from Siklos (1990), these series are based on original Hungarian National Archives data and runs from January 1 to July 24, 1946. The original series was log-transformed and also differenced to create the two different series utilized here. 
Level and change in the daily exchange rate (pengö to US dollar), from October 22, 1945 to May 14, 1946: This data also was taken from Sikos (1990) and, as above, the original series was differenced to create the two different series utilized here.

Level (in logs) and growth of the daily index of prices denominated in tax pengö: As noted in the text, the tax pengő was introduced on January 1, 1946 mainly as a way to fight inflation; however, as Bomberger and Makinen (1983) show, the partially-indexed bank accounts denominated in tax pengő actually worsened the hyperinflation (mainly because the indexing was lagged by sometimes as much as two days). Given its short life span, this series only runs on a daily basis from January 1 through July 29, 1946 and was originally collated by Siklos (1990). As with the previous two series, differences were taken to create a growth rate while, as with the Cost of Living index, the underlying series was log-transformed to take into account its explosive nature. 
Table A1 - Summary Statistics for Hungarian Data Series

\begin{tabular}{|c|c|c|c|c|c|c|c|c|c|c|c|}
\hline & $\begin{array}{l}\text { Percentage } \\
\text { Change of } \\
\text { Bills in } \\
\text { Circulation }\end{array}$ & $\begin{array}{c}\text { Exchange } \\
\text { Rate } \\
\text { Index, } \\
\text { 1914-25 }\end{array}$ & $\begin{array}{l}\text { Change } \\
\text { in the } \\
\text { Exchange } \\
\text { Rate } \\
\text { Index, } \\
\text { 1914-25 }\end{array}$ & $\begin{array}{l}\text { Exchange } \\
\text { Rate } \\
\text { Value, } \\
1914-25\end{array}$ & $\begin{array}{c}\text { Change } \\
\text { in } \\
\text { Exchange } \\
\text { Rate } \\
\text { Value, } \\
1914-25\end{array}$ & $\begin{array}{l}\text { Log } \\
\text { Cost of } \\
\text { Living } \\
\text { Index, } \\
1946\end{array}$ & $\begin{array}{l}\text { Growth of } \\
\text { Cost of } \\
\text { Living } \\
\text { Index, } \\
1946\end{array}$ & $\begin{array}{l}\text { Daily exchange } \\
\text { rate level, } \\
1945-46\end{array}$ & $\begin{array}{c}\text { Change in } \\
\text { daily } \\
\text { exchange } \\
\text { rate, } \\
1945-46\end{array}$ & $\begin{array}{l}\text { Log of } \\
\text { the level } \\
\text { of tax } \\
\text { pengo } \\
\text { price } \\
\text { index, } \\
\text { daily, } \\
1946\end{array}$ & $\begin{array}{c}\text { Growth of } \\
\text { the tax } \\
\text { pengo } \\
\text { price } \\
\text { index, } \\
\text { daily, } \\
1946\end{array}$ \\
\hline Mean & 0.0054 & 28.911 & -0.067 & 2802.923 & 0.067 & 20.798 & 0.367 & 44974486.00 & 0.073 & 9.491 & 0.246 \\
\hline Median & 0.0089 & 3.200 & -0.018 & 34.320 & 0.018 & 15.141 & 0.114 & 385750.00 & 0.060 & 4.625 & 0.092 \\
\hline Maximum & 0.5533 & 104.920 & 0.399 & 18482.000 & 2.459 & 70.234 & 8.333 & 1090000000.00 & 1.319 & 49.047 & 3.564 \\
\hline Minimum & -0.9398 & 0.006 & -0.981 & 1.000 & -2.100 & 10.723 & -0.087 & 2300.00 & -1.283 & 0.000 & -1.124 \\
\hline Std. Dev. & 0.0912 & 34.448 & 0.175 & 5574.577 & 0.321 & 13.610 & 0.785 & 151000000.00 & 0.161 & 11.965 & 0.432 \\
\hline Skewness & -4.0127 & 0.780 & -1.438 & 1.720 & 0.926 & 2.028 & 6.873 & 4.69 & -0.883 & 1.760 & 3.031 \\
\hline Kurtosis & 59.4818 & 2.178 & 8.718 & 4.187 & 37.158 & 6.647 & 67.045 & 26.81 & 54.531 & 5.274 & 20.190 \\
\hline Jarque-Bera & 29969.4900 & 18.532 & 244.077 & 78.892 & 6972.306 & 202.070 & 28962.290 & 4367.44 & 17723.460 & 145.686 & 2754.708 \\
\hline Probability & 0.0000 & 0.000 & 0.000 & 0.000 & 0.000 & 0.000 & 0.000 & 0.000 & 0.000 & 0.000 & 0.000 \\
\hline Observations & 221 & 143 & 143 & 143 & 143 & 163 & 162 & 160 & 160 & 199 & 199 \\
\hline
\end{tabular}

